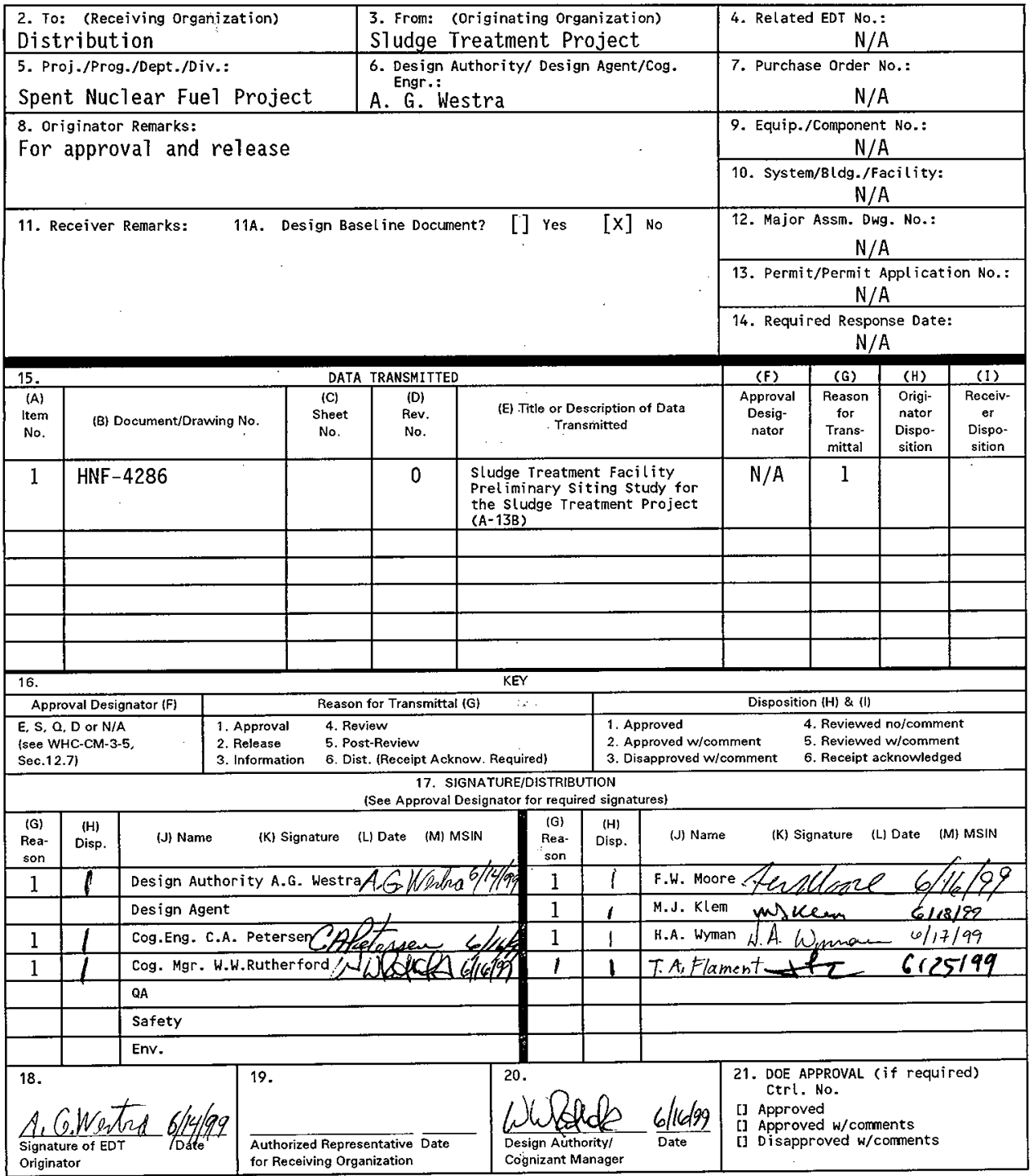




\title{
Sludge Treatment Facility Preliminary Siting Study for the Sludge Treatment Project (A-13B)
}

\author{
A. G. Westra, F. W. Moore, M. J. Klem, H. A. Wyman
}

Numatec Hanford Corporation

Richland, WA 99352

U.S. Department of Energy Contract DE-AC06-96RL13200

EDT/ECN: 626300

Org Code: 82500

B\&R Code: EW7040000
UC: 2000

Charge Code:

Total Pages: 58

Key Words: S1udge, K Basins, treațent, siting, study

Abstract: This study evaluates various sites in the $100 \mathrm{~K}$ area and 200 areas of Hanford for locating a treatment facility for sludge from the $K$ Basins. Both existing facilities and a new standalone facililty were evaluated. A standalone facility adjacent to the AW Tank Farm in the 200 East area of Hanford is recommended as the best location for a sludge treatment facility.

TRADEMARK DISCLAIMER. Reference herein to any specific comercial product, process, or service by trade name, trademark, manufacturer, or otherwise, does not necessarily constitute or imply its endorsement, recommendation, or favoring by the United States Government or any agency thereof or its contractors or subcontractors.

Printed in the United States of America. To obtain copies of this document, contact: Document Control Services, P.0. Box 950, Mailstop H6-08, Richland WA 99352, Phone (509) 372-2420; Fax (509) 376-4989.
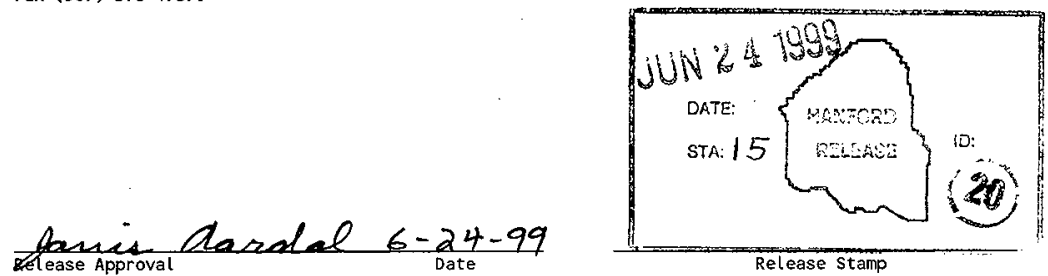

\section{Approved for Public Release}




\section{HNF-4286 \\ Sludge Treatment Facility Preliminary Siting Study for the Sludge Treatment Project (A-13B)}

Prepared by

A. G. Westra

B\&W Hanford Company

Richland, Washington

F. W. Moore

Numatec Hanford Corporation

Richland, Washington

M. J. Klem

COGEMA Engineering Corporation

Richland, Washington

H. A. Wyman

COGEMA Engineering Corporation

Richland, Washington

June 1999 


\section{Table of Contents}

1 EXECUTIVE SUMMARY 1

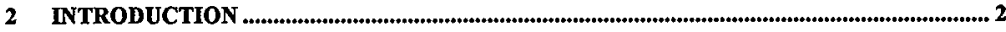

2.1 PURPOSE

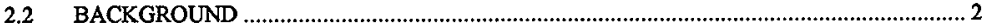

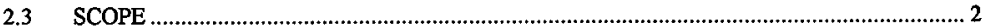

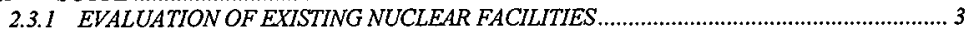

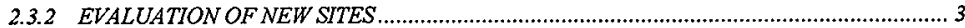

3 METHODOLOGY FOR THE SLUDGE TREATMENT FACILITY SITING......................... 3

4 DESCRIPTION OF THE SLUDGE TREATMENT PROCESS REQURING A NUCLEAR

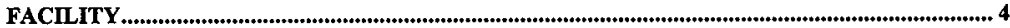

5 CONSIDERATION OF EXISTING NUCLEAR FACILITIES .......................................... 12

5.1 MINIMUM NUCLEAR FACILITY REQUIREMENTS ................................................ 12

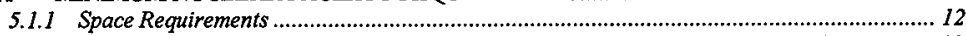

5.2 CRTTERIA FOR USE OF EXISTING FACLITIES ....................................................... 12

5.3 POTENTIAL USE OF EXISTING NUCLEAR FACILITIES ............................................. 13

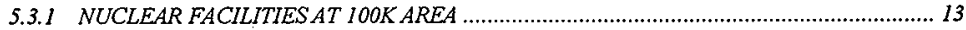

5.3 .2 NUCLEAR FACILITIES IN 200 EAST AND WEST AREAS ......................................... 15

5.4 EVALUATION OF THE EXISTING NUCLEAR FACILITIES......................................... 24

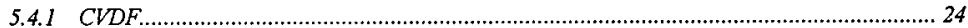

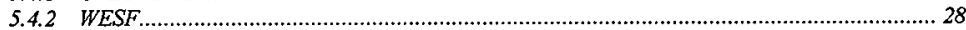

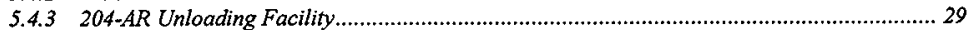

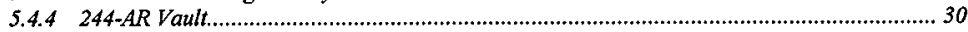

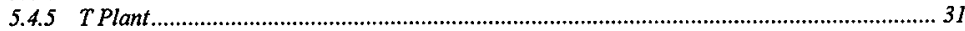

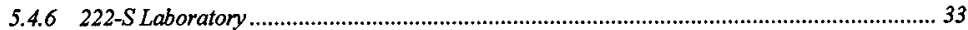

5.5 RECOMMENDATION FOR USE OF EXISTING FACILITIES ........................................ 35

5.5.1 Development Criteria and Evaluation for Existing Facilities.............................................. 35

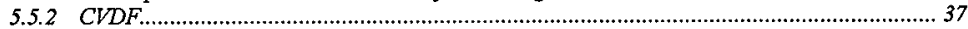

5.5.3 WESF

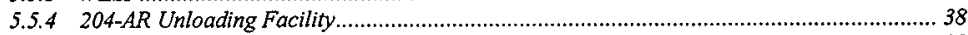

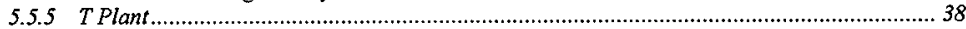

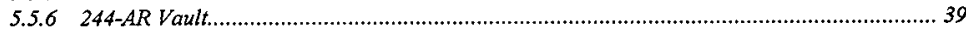

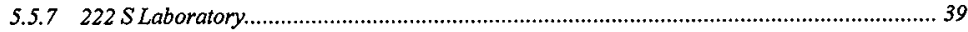

6 CONSWERATION OF A NEW STAND-ALONE NUCLEAR FACIITY............................... 40

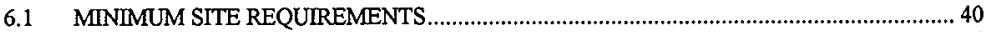

6.I.I SPACE

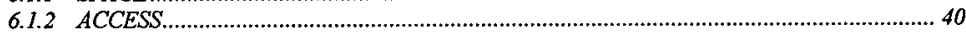

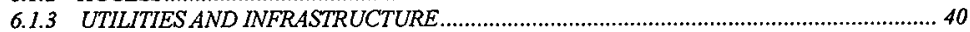

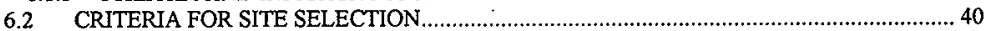

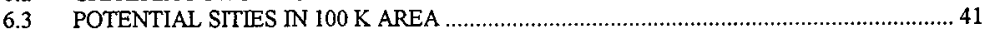

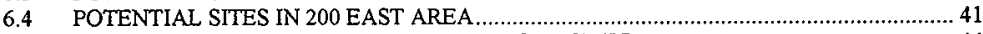

6.5 EVALUATION OF POTENTIAL STAND-ALONE SITES ............................................... 44

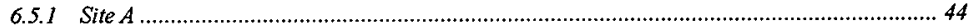

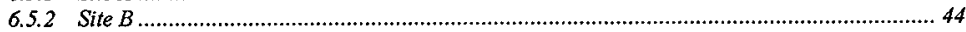

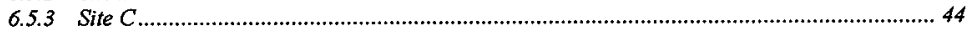

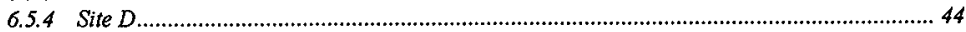

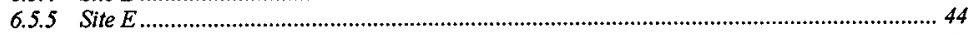

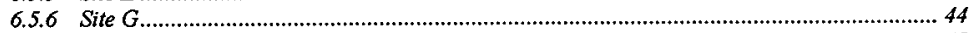

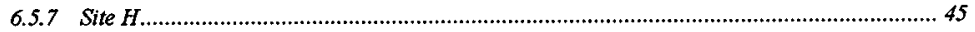




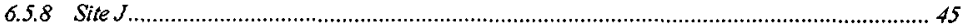

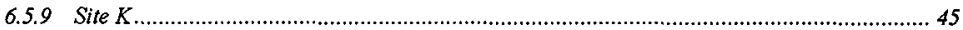

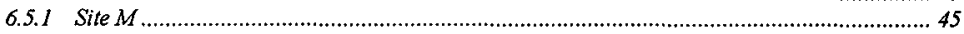

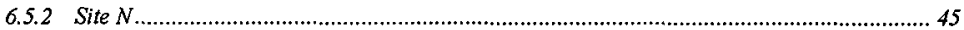

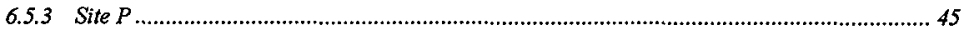

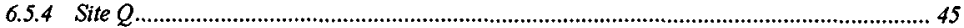

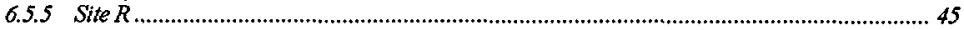

6.6 RECOMMENDATION FOR NEW STAND-ALONE FACILITY SITE............................. 46

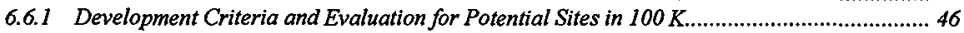

6.6.2 Development Criteria and Evaluation for Potential Sites in 200 Area................................. 49

7 ENGINEERING ANALYSIS AND RECOMMENDATION............................................. 51

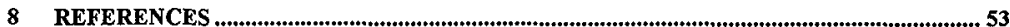


HNF-4286, Rev. 0

\section{EXECUTIVE SUMMARY}

This engineering study identifies and evaluates the alternatives for siting a Sludge Treatment Facility for chemically treating the $\mathrm{K}$ Basins sludge during a short 13 month campaign. The chemically treated sludge would be transferred to the Tank Waste Remediation System (TWRS) double shell tank (DST) 241-AW-105 for interim storage. Before this study was completed, a decision was made to change the path forward for $\mathrm{K}$ Basin sludge from chemical treatment during a 13-month period to interim storage at $\mathrm{T}$ Plant (Williams, 1999). This study is being issued to document information that formed part of the basis for the new path forward.

The recommendation of this study is that the primary site for the location of a Sludge Treatment Facility is a new stand-alone facility at a site adjacent to the south perimeter fence of the Double Shell Tank AW Farm. This site is designated M in this study. The consideration of being close to DST AW-105 for transfer/transportation purposes, being away from the river and site boundaries for siting of a chemical treatment facility, provide the siting in the 200 East Area as the best choice. This will also incur the lowest transportation cost and is the primary recommendation for transport of the sludge identified in the transportation study (Klem, 1999). Since this facility will have a very short primary mission of less than three years it is desirable to construct a facility at a minimum cost. The maximum distance from public access (the river and site boundary) will allow for lower costs associated with the Design Basis Accident mitigation and will better support the site mission of cleaning up the sites close to the river.

The recommendation for the alternate site for the location of a Sludge Treatment Facility, if the above site cannot be used, is a new stand-alone facility at a site which is 200 meters south of the south perimeter fence of Double Shell Tank AW farm. This site (designated $\mathrm{R}$ in this study) is less congested for space and is close enough to use the short pipeline concept (Klem, 1999) though the costs will be somewhat higher than the primary site. The primary site has advantages that apply to the alternate site as well.

The T Plant canyon deck is being considered for the site of a facility to process the remote handled TRU waste currently stored in the $200 \mathrm{~W}$ area (Tri-party Agreement milestone M91). If the T Plant structure and documentation are upgraded to process remote handled transuranic (RH TRU) waste, then many of the upgrades that would be needed to treat the $\mathrm{K}$ Basin sludge probably will already be done. The sludge treatment equipment and control system would need to be installed, but the building structure and shielding would already be in place. After the sludge treatment campaign is completed, the sludge treatment equipment probably could be used to process some of the RH TRU waste.

If the burden of T Plant upgrades to process sludge fell entirely to the Spent Nuclear Fuel Project, the cost might equal or exceed the cost of a new stand-alone facility. The extent of the needed upgrades are as yet unknown, but this assessment is made based upon needed improvement to other similar facilities for similar missions. If T Plant is considered for an RH TRU mission, and K Basin sludge could be processed with it as 
HNF-4286, Rev. 0

part of a shared mission and managed as RH TRU waste rather than go to TWRS, the option to use T Plant should be revisited.

\section{INTRODUCTION}

\subsection{PURPOSE}

The purpose of this study is to evaluate the existing nuclear facilities and a new standalone nuclear facility at potential sites at $100 \mathrm{~K}$ Area, 200 East Area, and $200 \mathrm{West}$ Area of the Hanford Site, and then make recommendations for the location of a Sludge Treatment Facility that would use the baseline chemical treatment process described in section 4.0 .

\subsection{BACKGROUND}

The KE and KW basins are used to store about 2100 metric tons of spent nuclear fuel (SNF) from Hanford Site production reactors. The floor and pits of the basins contain sludge from fuel corrosion, concrete spalling, and sand infiltration. The SNF will be removed from the basins, and stored in the Canister Storage Building (CSB). Following fuel removal, the sludge will be removed from the basins and transferred to a sludge treatment facility. Sludge from the canisters and fuel washing will also be transferred to the sludge treatment facility. There the sludge will be chemically treated to meet waste tank acceptance criteria and then transferred to a double shell waste tank.

The preconceptual design report for sludge treatment located the sludge treatment facility in the spare bay of the Cold Vacuum Drying Facility (CVDF). The equipment was designed for installation on skid mounted modules that could be fabricated at another location at Hanford or off-site and then moved to the CVDF or another location and connected together. The CVDF has been the baseline location for the sludge treatment facility since the K Basins Sludge Removal Sludge Pretreatment System Preconceptual Design report (Chang, H. L., 1997) was completed in June 1997. The baseline process for sludge treatment has changed significantly since that time which impacts the site selection process.

\subsection{SCOPE}

The scope of this document is limited to preliminary site selection for the K Basin Sludge Treatment Facility conceptual design. This document only applies to a facility for treating the sludge in a 13 month period using the baseline chemical treatment process described in section 4.0. If an alternate treatment process for the sludge is selected, or the processing time is extended, then the conclusions of this study should be reexamined. Only sites in the $100 \mathrm{~K}$ and 200 areas were considered. Existing facilities in the 300 area (325 Building) and 400 area (FMEF) were not considered due to the much longer distance that the sludge would need to be shipped and because the sludge would have to be shipped over public highways which could require a DOT licensed transportation 
system or road closure. The sludge would have to be trucked both to and from these facilities. There are also other reasons for not including the 300 Area and 400 Area facilities. FMEF was designed as a dry processing facility so it has no provisions for handling high radiation dose rate liquids. Locating the sludge treatment facility in the 325 Building in the 300 Area would be opposed by stakeholders since it is near the Columbia River and the City of Richland.

The $\mathrm{K}$ Basins also were not evaluated as a potential location for the sludge treatment facility. The basins have limited space and interference between construction of the sludge treatment facility and fuel removal operations would be a problem. The only area inside the basins where the sludge treatment process could be built is the loadout area. Water treatment equipment including piping, ion exchange modules, and the sand filter would have to be removed. Even with these changes the space is limited and inflexible. The loadout area will be used to load fuel into MCOs, and load casks onto the transport trailers. Construction activities in the loadout area are incompatible with these operations.

\subsubsection{EVALUATION OF EXISTING NUCLEAR FACILITIES}

The scope of this document examines the possibility of locating the sludge treatment facility in an existing nuclear facility. Using an existing facility would be beneficial in the economics, environmental, and schedule aspects of the project. In this document, the existing facilities that are examined are the Cold Vacuum Drying Facility (CVDF), the 204-AR Unloading Facility, the Waste Encapsulation and Storage Facility (WESF), the 244-AR Vault, the T-Plant Canyon Facility, and the 222 - S Laboratory.

\subsubsection{EVALUATION OF NEW SITES}

The scope of this document also examines the possibility of locating the sludge treatment facility in a new stand-alone facility. Building a new stand-alone facility would be beneficial assuming that no existing facilities are capable of housing the sludge treatment process based on economic constraints, nuclear containment constraints, space availability constraints, or accessibility constraints. Locations will be examined in both $100 \mathrm{~K}$ and 200 areas.

\section{METHODOLOGY FOR THE SLUDGE TREATMENT FACILITY SITING}

The methodology used in this document is based on the guidance from DOE/MA/062122 Site Development Planning Handbook Supplement, Good Practice Guide GPG-FM-033 Comprehensive Land-Use Planning Process Guide, (DOE, 1996a), and Good Practice Guide GPG-FM-024 Site Selection Processs (DOE 1996b). The sludge treatment will be under the Comprehensive Environmental Response and Liability Act of 1980 (CERCLA). This document will support the focused feasibility study (DOE-RL, 1999) 
prepared to support the CERCLA process and will be used to support selection of an appropriate treatment and disposition pathway for the sludge. The CERCLA review process provides for obtaining public participation in the siting and planning process. The Spent Nuclear Fuel Project Systems Engineering Management Plan WHC-SD-SNFSEMP-001 (Womack, 1996) encompasses the efforts necessary to manage systems engineering implementation for the SNF project. The recommendation when implemented will support the Functional Requirements Baseline.

This sludge treatment process will require a nuclear facility. Existing nuclear facilities in the $100 \mathrm{~K}$ Area and the 200 Areas will be evaluated. If an existing nuclear facility is not found suitable to house the sludge treatment process, then various alternatives for a standalone nuclear facility sites will be evaluated. Criteria for existing nuclear facilities will be established and a evaluation team will evaluate the existing sites. Criteria for new standalone nuclear facility will be established and an evaluation team will evaluate the site alternatives. Then the existing facilities and sites that survive the first cut minimum criteria will be further evaluated. A preferred site and a backup alternative will be recommended as the preliminary sites during the conceptual design of the Sludge Treatment Facility.

\section{DESCRIPTION OF THE SLUDGE TREATMENT PROCESS REQUIRING A NUCLEAR FACILITY}

The baseline chemical treatment process for $\mathrm{K}$ Basin sludge is described in the $\mathrm{K}$ Basin Sludge Treatment Process Description (Westra, 1998a) and summarized in the following paragraphs.

The sludge will be transferred from the basins to the treatment system in a shielded transport container or through a pipeline. The sludge will be pumped from the transport container or through a pipeline into the lag storage tank of the new process where it will be held until it can be processed. Sludge treatment will be done by dissolving the fuel constituents in nitric acid, separating the insoluble material, adding neutron absorbers for criticality safety, and reacting the solution with caustic to co-precipitate the uranium, iron, and plutonium ions. The resulting slurry will be transported to an underground storage tank (most likely tank 241-AW-105) for interim storage. If the facility is located near the AW Tank Farm, a pipeline instead of a shielded transport container can be used to transfer the slurry to AW-105.

Sludge treatment will include the following steps:

- Sludge transfer from transport container to lag storage vessel

- Resin bead separation

- Acid addition to the dissolver

- Sludge transfer from sludge buffer tank to dissolver

- Sludge dissolution

- Solution transfer from dissolver 
- Solids/liquid separation

- Absorber addition (after sampling)

- Neutralization/precipitation.

- Slurry transfer to tank farm.

The portion of the sludge that is not dissolved will go through the following steps:

- Solids/liquid separation

- Solids washing

- Chemical treatment of solids for removal of ${ }^{137} \mathrm{Cs}$ and TRU

- Solids/liquid separation

- Solids washing

- Stabilization in grout.

The resin beads that are separated upstream from the dissolver will go through the following steps:

- Chemical leaching for ${ }^{137} \mathrm{Cs}$ and TRU removal

- Solids/liquid separation

- Solids washing

- Stabilization in grout along with undissolved solids from the dissolver.

The dissolver off-gas system will consist of the following:

- Condenser

- $\mathrm{NO}_{\mathrm{x}}$ absorber

- Mist eliminator

- Heater

- HEPA filters

- Activated carbon cartridge

- Sampling/monitoring system

- Release from stack.

A maintenance and operations study for $\mathrm{K}$ Basin sludge treatment (Westra, 1998b) concluded that a hot cell would be the best maintenance and operation concept for a sludge treatment facility for the baseline chemical process. Hot cells have been built and operated for many years so they are a well developed and proven technology.

A preliminary layout (see Figures 4-1 and 4-2) for a stand-alone sludge processing facility containing a hot cell was prepared for the Sludge Treatment Alternatives Analysis (Pearce, 1999). The layout indicates that a hot cell with interior dimensions of approximately $5.5 \mathrm{~m} \mathrm{x} 12.2 \mathrm{~m} \mathrm{x} 4.3 \mathrm{~m}$ high $\left(18^{\prime} \times 40^{\prime} \times 14^{\prime} \mathrm{h}\right.$ ) would be required to house the main processing equipment. The $76 \mathrm{~cm}(2.5 \mathrm{ft})$ thick reinforced concrete 
Figure 4-1. Sludge Treatment Baseline Enlarged View Sheet 1
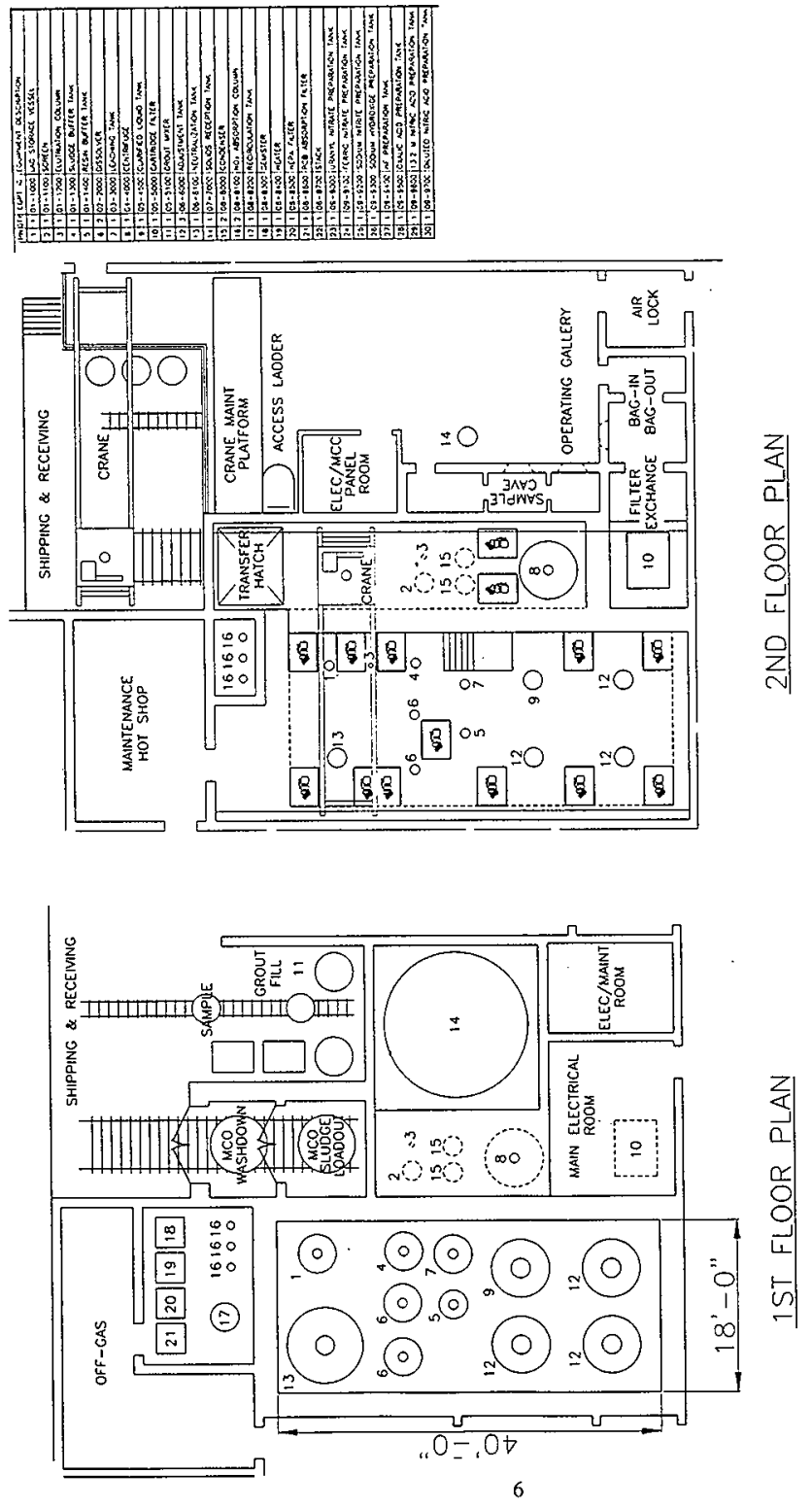
Figure 4-2. Sludge Treatment Baseline Enlarged View Sheet 2
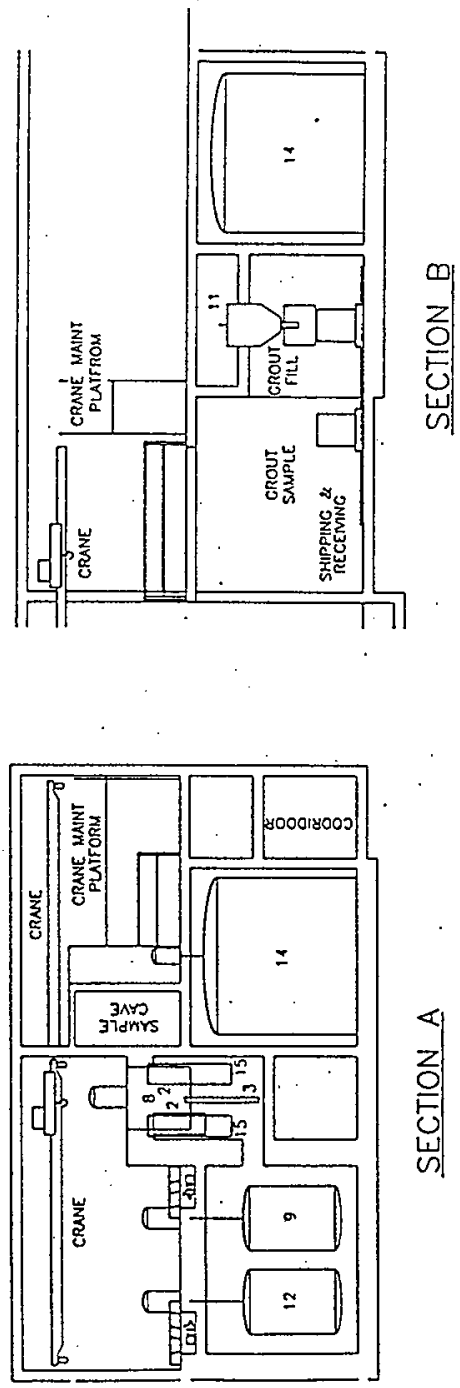
shielding of the hot cell walls would make the exterior dimensions approximately $7 \mathrm{mx}$ $13.7 \mathrm{~m} \times 5.2 \mathrm{~m}\left(23^{\prime} \times 45^{\prime} \times 17^{\prime} \mathrm{h}\right)$. A cell with these dimensions would have $67 \mathrm{~m}^{2}$ ( 720 $\mathrm{ft}^{2}$ ) of interior space. An extension on one side of the main cell would house the centrifuge, condensers, elutriation column, and screens that require more headspace than the other equipment in the cell. This section of the cell would extend up to $19.5 \mathrm{ft}$ high (bottom of cover blocks).

The dissolver off gas equipment downstream from the condensers, the undissolved solids tank, and the grouting equipment would be located outside the hot cell since the radiation dose from this equipment is expected to be low enough that little shielding is required (Hillesland, 1999). The load-in/load-out area, the large solids collection tank, and the grouting equipment would be located together adjacent to one side of the hot cell. If a cask is used to ship the sludge from $\mathrm{K}$ Basin, the large bridge crane would be used to transfer the sludge cask from the flatbed trailer to a location adjacent to the hot cell. After the sludge was pumped from the cask into the lag storage tank in the hot cell, the cask would be decontaminated and transferred back to the flatbed trailer. If a cask is used to transfer the treated sludge to the TWRS double shell tank, the crane would also be used to move this cask between the flatbed trailer and the load-out area. A second smaller bridge crane would be located above the hot cell and would be used for maintenance of the centrifuge and agitator motors. The chemical makeup tanks and sample cave would be located on the $2^{\text {nd }}$ level.

The dimensions of the processing building for a stand-alone sludge treatment facility would be approximately $30 \mathrm{~m} \times 33 \mathrm{~m}\left(100^{\prime} \times 110^{\prime}\right)$. The total building height would be

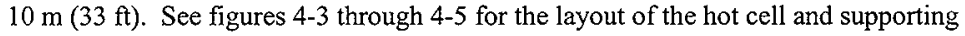
facilities for a stand-alone sludge treatment facility. Attached to the processing building would be a $15 \mathrm{~m}$ x $18 \mathrm{~m}\left(50^{\prime}\right.$ x 60') office and change room annex. Three bulk chemical tanks, water makeup tanks, a batch plant for grout, and some miscellaneous equipment would be located in basins or on pads outside the building. 
Figure 4-3. Sludge Treatment Baseline $1^{\text {st }}$ Floor Sheet 1
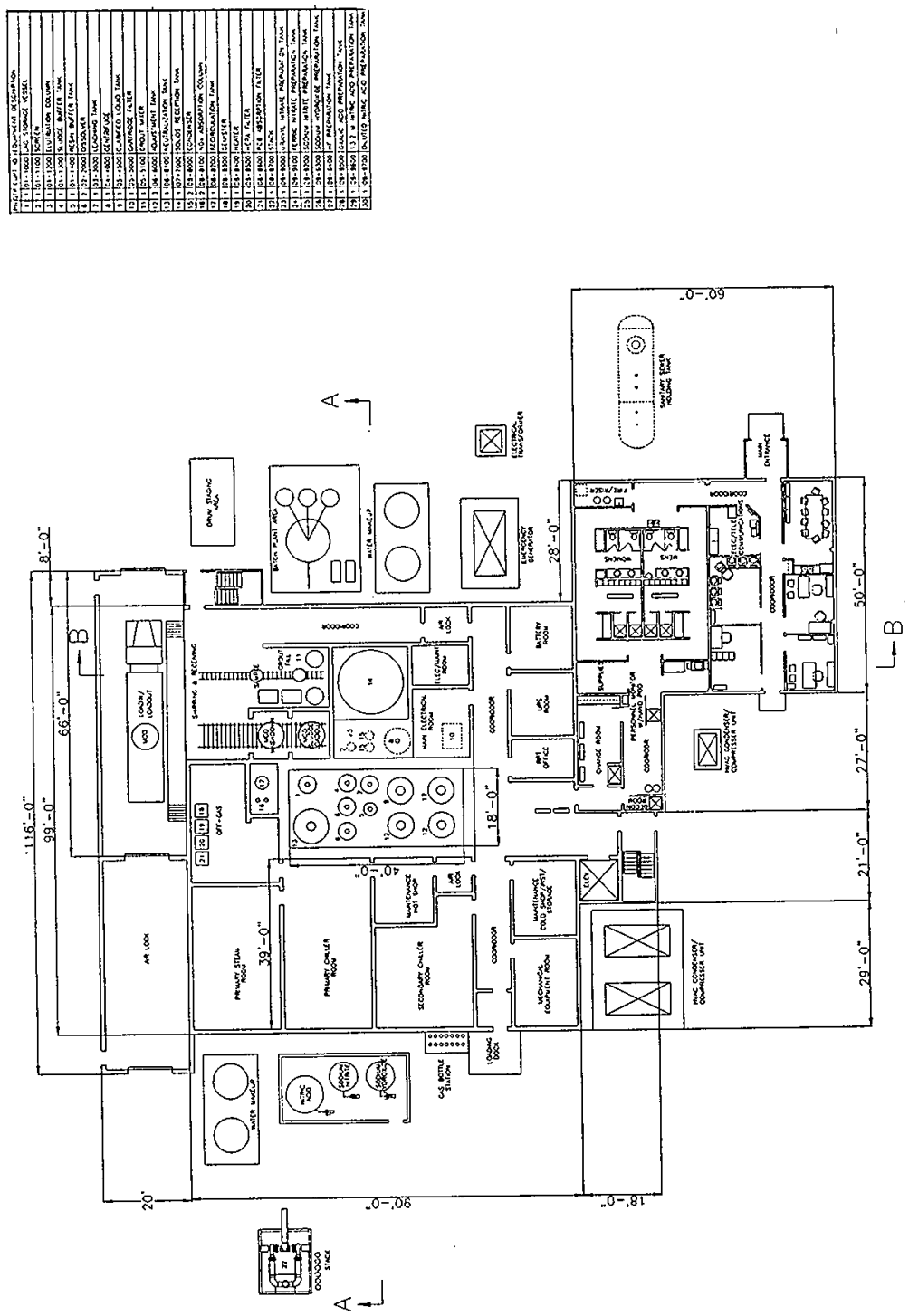
Figure 4-4. Sludge Treatment Baseline 2nd Floor Sheet 2

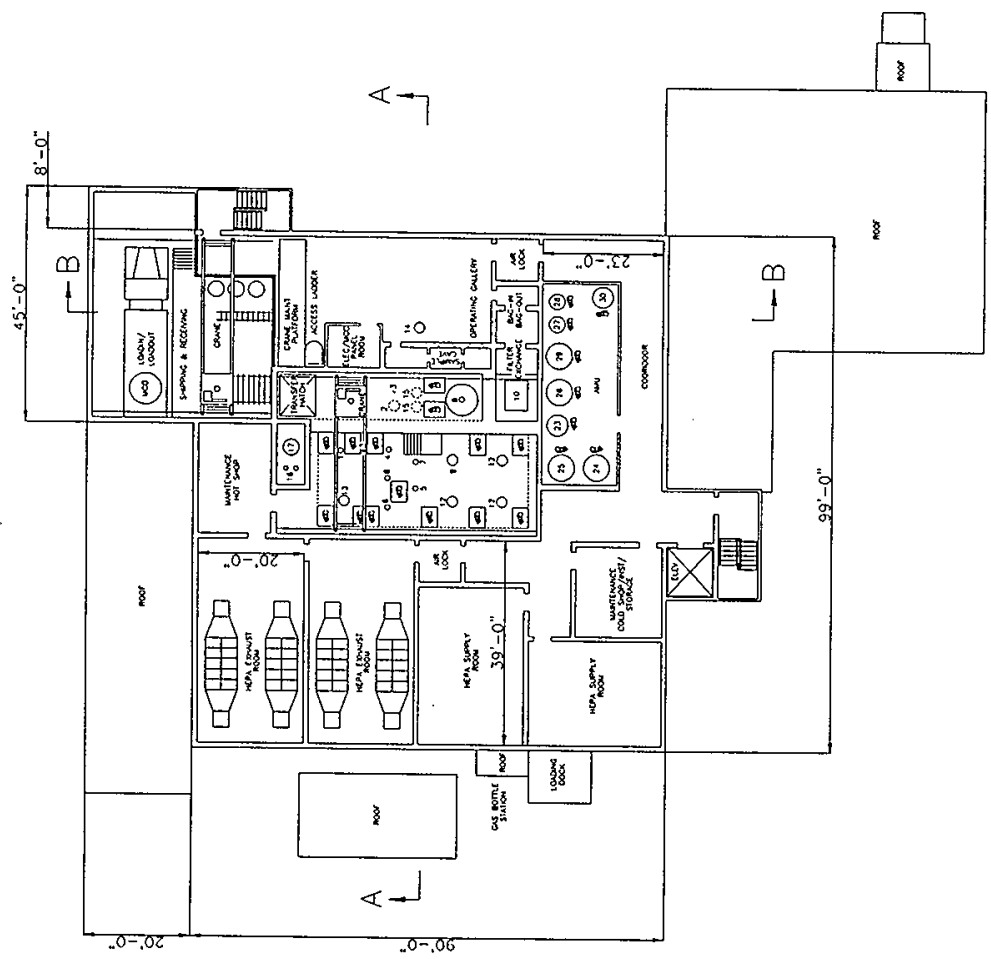


Figure 4-5. Sludge Treatment Baseline Sections Sheet 3
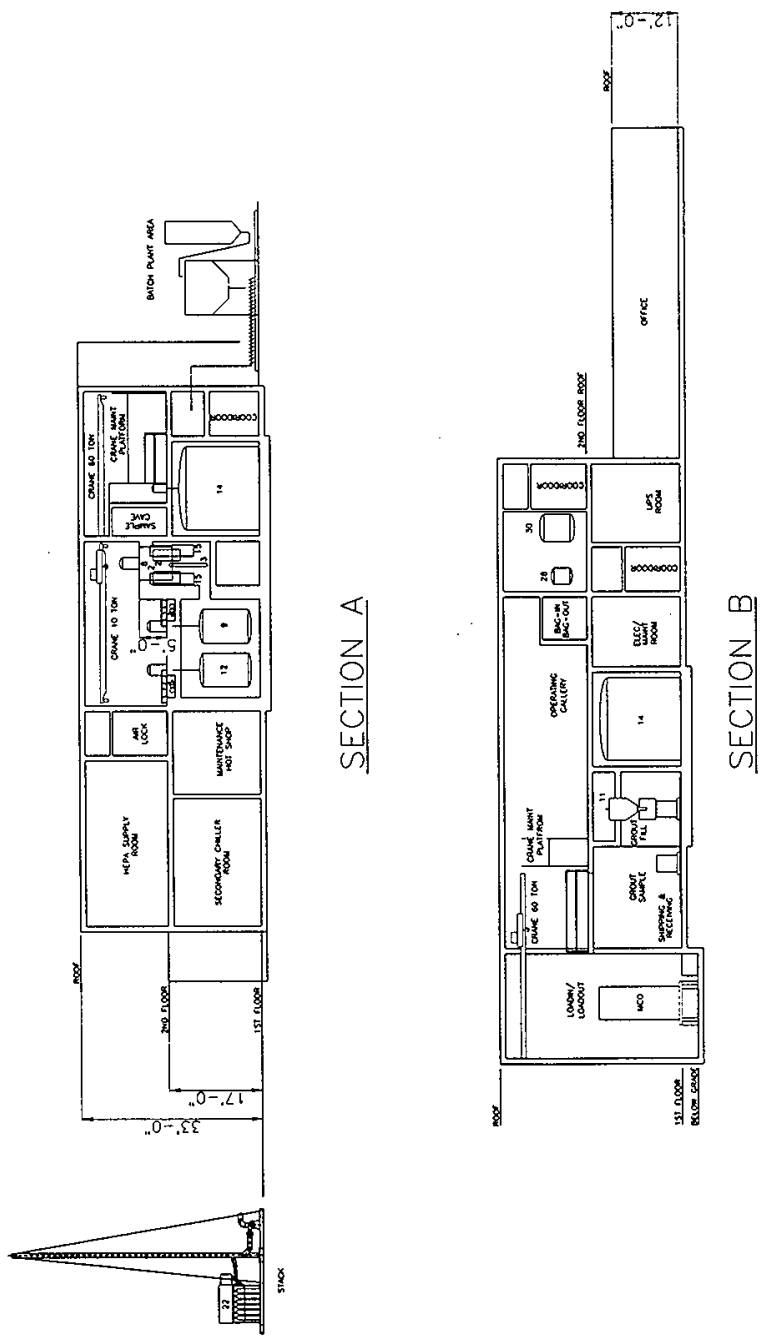


\section{CONSIDERATION OF EXISTING NUCLEAR FACILITIES}

\subsection{MINIMUM NUCLEAR FACILITY REQUIREMENTS}

\subsubsection{Space Requirements}

Any site considered for the Sludge Treatment Facility must have adequate space for the processing equipment, shielding, and support functions. The processing equipment needed for $\mathrm{K}$ Basin sludge treatment by chemical processing has been identified. Preliminary facility layout drawings have been prepared as part of the sludge treatment alternatives study. The preliminary facility layout drawings indicate that approximately $67 \mathrm{~m}^{2}\left(720 \mathrm{ft}^{2}\right)$ of hot cell space (interior) will be required to house the main processing equipment. If the equipment is installed in a single hot cell, the total floor space required for just the hot cell plus shielding would be approximately $96 \mathrm{~m}^{2}\left(1035 \mathrm{ft}{ }^{2}\right)$. Additional space will be needed for the processing equipment that will be located outside the hot cell, for a loadin/loadout truck bay, and for many other support functions. A list of the processing equipment outside the cell and the support functions that will be required is presented below.

Chemical makeup tanks

Dissolver off-gas system

Solids tank

Solids grouting equipment

Loadin/loadout truck bay

Closed loop heating and cooling systems

HVAC equipment

Control room

Change rooms

Lunch room

Management and engineering offices

Radiological control office

Decontamination room

\subsection{CRITERIA FOR USE OF EXISTING FACILITIES}

All considered existing nuclear facilities will have certain criteria that they will be compared against. This comparison will determine whether or not the existing facility is an acceptable location for the sludge treatment. The criteria that will be included in this examination are as follows:

- There should be enough space to meet the sludge treatment space requirements.

- The facility should be reasonably adaptable.

- The facility must meet all the safety requirements. 
- The facility should take into account the transfer/transport study (Klem,1999).

- The $200 \mathrm{E}$ area is preferred (less volume to transport via cask).

- Both pumping and cask transfer will be difficult, but for treated sludge, pumping a short distance is less expensive than to move via cask.

- The facility would be better off away from the river.

- The facility should not interfere with other projects, operating facilities, or ongoing operations.

- The installation of the process into the facility should not disrupt existing infrastructure.

- There should be no ground contamination surrounding the facility that would impact modifications (prior spills or disposal).

\subsection{POTENTIAL USE OF EXISTING NUCLEAR FACILITIES}

\subsubsection{NUCLEAR FACILITIES AT 100 K AREA}

\subsubsection{Cold Vacuum Drying Facility}

The CVDF is a nuclear facility located within a few hundred meters of the $100 \mathrm{~K}$ Basins just southwest of the $165 \mathrm{KW}$ Power Control Building and the $105 \mathrm{KW}$ Reactor Building.

The CVDF building is an above-grade structure approximately $70 \mathrm{~m}(230 \mathrm{ft})$ long and $24.4 \mathrm{~m}(80 \mathrm{ft})$ wide see Figure 5-1. The CVDF structure has four significant sections. The building consists of the process area, process water tank room, process support area, and administrative area. The process area $(18.3 \mathrm{~m}$ by $45.7 \mathrm{~m}$ [60 ft by $150 \mathrm{ft}])$ contains four process bays (plus one unused bay without services) with an adjoining process water tank room $(6 \mathrm{~m}$ by $12.1 \mathrm{~m}$ [ $20 \mathrm{ft}$ by $40 \mathrm{ft}])$. These areas are constructed as a single-story, steel-frame building with $25.4-\mathrm{cm}$ (10-in.) thick exterior walls of precast concrete panels. The process support area $(6.1 \mathrm{~m}$ by $45.7 \mathrm{~m}[20 \mathrm{ft}$ by $150 \mathrm{ft}])$ includes the transfer corridor and adjacent rooms, along with the second-floor mechanical room, and is constructed as a two-story steel frame building with an exterior skin of metal siding. The administrative area is an adjacent, single-story, pre-engineered metal building with an exterior skin of insulated metal panels. All roof decks are metal.

Each of the four process bays is designed to enclose a MCO cask transporter, without the tractor attached, and to provide the operational space necessary to meet the function of the CVDF. The process bay design provides radiological separation and shielding between bays and ventilation confinement within each bay.

The process bay building design uses a steel frame and prestressed concrete panel system that has a bay width of $9.14 \mathrm{~m}(30 \mathrm{ft})$ and a nominal length of $18.28 \mathrm{~m}(60 \mathrm{ft})$. The height

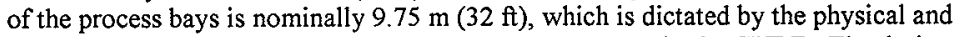
functional requirements for all of the operations necessary in the CVDF. The design concept uses a steel frame with attached epoxy-coated concrete panels to facilitate decontamination and dismantlement. 


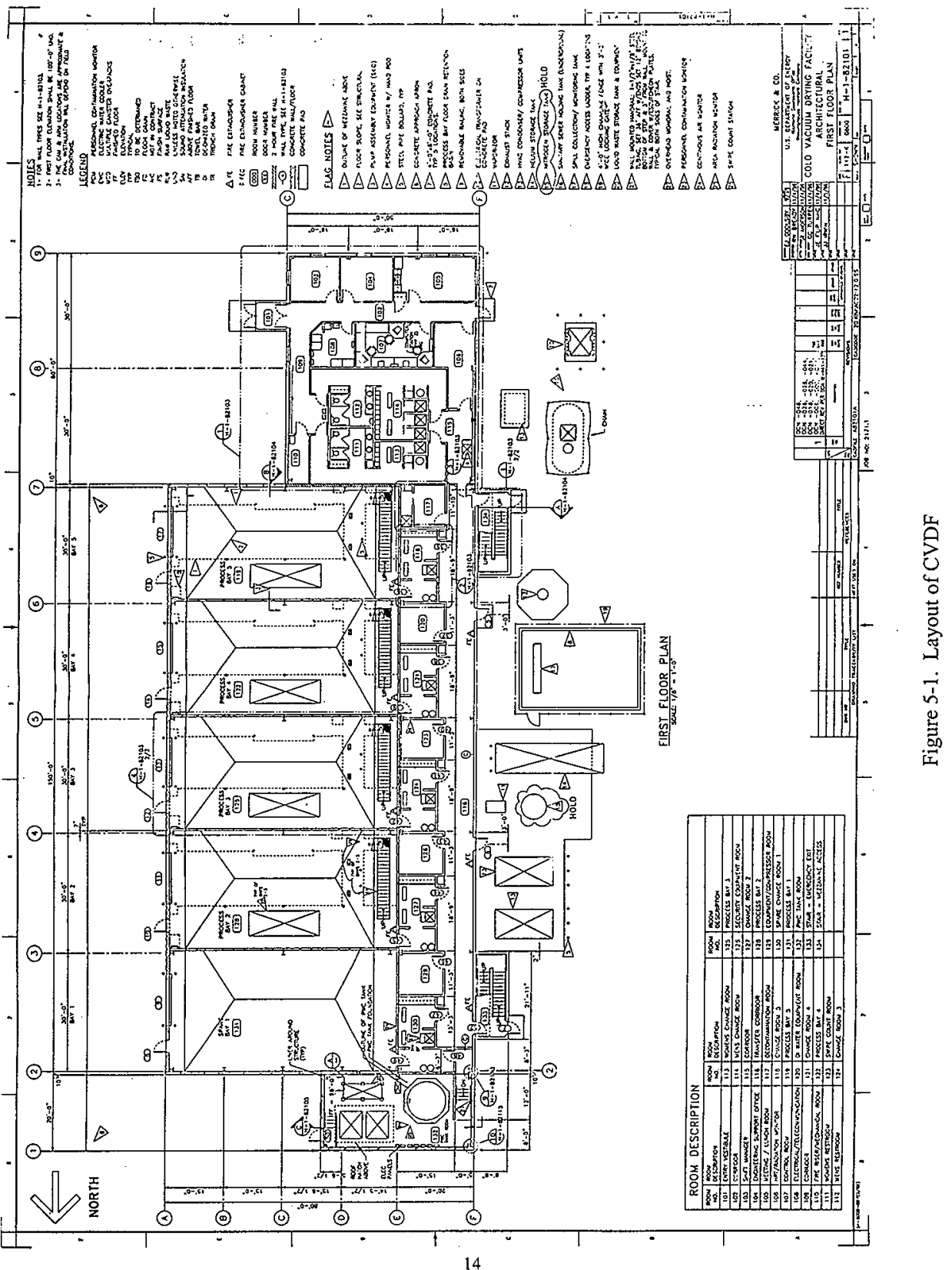


The floor of the process bays is made of an 8-in thick re-enforced concrete slab over 4 inches of 5/8" minus crushed gravel except for the wall footings and the areas that will support the cask transporter. The two areas in each bay that will support the cask transporter are supported by footings to give a total concrete thickness of at least $81 \mathrm{~cm}$ $\left(2^{\prime} 9^{\prime \prime}\right)$. These footings support $27 \%\left(477 \mathrm{ft}^{2}\right)$ of the floor space in each bay.

Each bay includes an overhead bridge crane with a capacity of $1,800 \mathrm{~kg}(4,000 \mathrm{lb})$. The bridge, trolley, and hoist are driven by electric motors and are capable of operation from the ground floor or mezzanine level.

The CVDF footprint includes approximately $3,090 \mathrm{~m}^{2}\left(12,800 \mathrm{ft}^{2}\right)$ for the process bays, process water tank room, and process support areas and $915 \mathrm{~m}^{2}\left(3,000 \mathrm{ft}^{2}\right)$ for administrative and change room functions. The design occupancy of the CVDF has been identified as 20 persons.

The CVDF has been given a preliminary designation of a hazards category 2 nuclear facility (Pili-Vincens, 1998). The CVDF ventilation system is non-safety class. The design basis river flood level, assuming a $25 \%$ breach of Grand Coulee Dam, is $140 \mathrm{~m}$ $(460 \mathrm{ft})$. The elevation of the CVDF is $145 \mathrm{~m}(476 \mathrm{ft})$ above mean sea level.

\subsubsection{NUCLEAR FACILITIES IN 200 EAST AND WEST AREAS}

\subsubsection{204-AR Unloading Facility}

The 204-AR unloading facility is a nuclear facility used to unload radioactive waste from railcars or trucks and transfer it to the double shell waste tanks. The 204-AR facility consists of a $6.1 \mathrm{~m} \times 23 \mathrm{~m}(20 \mathrm{ft} \times 75 \mathrm{ft})$ shielded truck/tank car bay, a mechanical equipment room, change rooms, and office space. A balcony on the second floor of the bay provides access for connecting transfer and vent lines to the tank truck or rail car. The 204-AR facility is equipped for in-line adjustment of waste as it is pumped from a railcar or truck to a waste tank. It has $\mathrm{NaOH}$ and $\mathrm{NaNO}_{2}$ tanks and pumps to supply the chemicals for in-line adjustment. These tanks are located in a room shielded from the unloading area. There is also a $56801(1500 \mathrm{gal})$ catch tank that can be used to adjust waste and then pump it to the waste tanks. This tank does not have an agitator for suspending solids. There is a double encased transfer line from 204-AR to tank AW-105.

The Operating Specifications Document (OSD) for 204-AR currently limits the waste that is allowed into the facility to $\mathrm{a} \mathrm{pH}$ of greater than 7 .

The 204-AR facility does not have any shielded space except for the unloading bay so it can only be considered for a sludge unloading and neutralization, not for sludge treatment. 


\subsubsection{Waste Encapsulation and Storage Facility}

The Waste Encapsulation and Storage Facility (WESF) is a nuclear facility located in the $200 \mathrm{E}$ area adjacent to the west end of B Plant. WESF looks attractive as a site for the sludge processing facility because it is an active hot cell facility with an off gas system that meets current standards. WESF contains six hot cells that were used to process and package cesium chloride and strontium fluoride into capsules. See Figure 5-2 for a layout of the hot cells. The $\mathrm{Cs}$ and $\mathrm{Sr}$ capsules are currently stored in the WESF storage pool. The cells are lined up in a single row with interconnecting lines between the cells. Two of the hot cells ( $F$ and $G$ ) are needed to store or overpack capsules from the WESF pool cell in case of a faulty capsule. The other four hot cells (A, B, C, and D/E) are no longer needed by WESF and will be available for sludge processing or other missions.

Cell $\mathrm{A}$ is $3 \mathrm{~m} \times 2.4 \mathrm{~m} \times 4.1 \mathrm{~m}$ (10 $\mathrm{ft}$ wide by $8 \mathrm{ft}$ deep by $13 \mathrm{ft} 6$ inches) high. Cells B and $\mathrm{C}$ are $2.44 \mathrm{~m} \times 2.44 \mathrm{~m} \times 3.9 \mathrm{~m}$ ( $8 \mathrm{ft} \times 8 \mathrm{ft}$ by $12 \mathrm{ft} 10$ in high). The floor in the rear half of $B$ and $C$ cells is elevated $56 \mathrm{~cm}$ ( 22 inches) above the rest of the floor. The last available cell D/E is a double wide cell with dimensions of $5.5 \mathrm{~m} \mathrm{x} 2.44 \mathrm{~m} \times 3.9 \mathrm{~m}(18 \mathrm{ft}$ wide by $8 \mathrm{ft}$ deep by $12 \mathrm{ft} 10$ inches tall). The floor in the rear half of the $D$ portion of $\mathrm{D} / \mathrm{E}$ cell is elevated $25 \mathrm{~cm}$ (10 inches) above the rest of the floor.

The floor and lower portion of the walls in A, B, and C cells are lined with 14 gauge type 304L stainless steel. The floor and lower portion of the walls in D/E cell are lined with 14 gauge Inconel-600 alloy. The cells are all equipped with sumps with level alarms. Any liquid draining to the sumps can be transferred to the low level waste system. Cells $A$ and $D / E$ each have two shielded viewing windows with a pair of master-slave manipulators for each window. Cells $B$ and $C$ each have one shielded viewing window with a pair of manipulators. All of the cells have cover blocks that can be removed by a bridge crane located in the shielded canyon area above the hot cells. Some of the old equipment has been removed from the hot cells, but all of the available cells except $A$ cell are still highly contaminated with $\mathrm{Cs}-137$ and $\mathrm{Sr}-90$.

The WESF canyon is $7.8 \mathrm{~m} \times 30.8 \mathrm{~m}$ ( $25.5 \mathrm{ft}$ wide $\times 101 \mathrm{ft}$ long). It has $76 \mathrm{~cm}$ ( 30 inches) of concrete shielding on the north and east sides which face the aqueous makeup and maintenance areas. The shielding thickness reduces to $46 \mathrm{~cm}$ (18 inches) at an elevation of $4 \mathrm{~m}(13 \mathrm{ft}$ ) above the canyon deck. The shielding on the outside walls (south and west) is $1-\mathrm{ft}$ thick concrete. The cover blocks for the hot cells occupy the north half of the canyon deck, while the south half is open deck except for a $2.4-\mathrm{m} \times 3.7-\mathrm{m}$ (8-ft $\mathrm{x}$ 12 -ft) cover block at the west end which can be removed to give the crane access to the truck bay. The crane is located $4.4 \mathrm{~m}(14.5 \mathrm{ft})$ above the canyon deck. The section of open canyon deck that could be used for sludge processing equipment is approximately 3 $\mathrm{m} \times 23 \mathrm{~m}$ (10 ft wide $\times 75 \mathrm{ft}$ long) with an area of $70 \mathrm{~m}^{2}\left(750 \mathrm{ft}^{2}\right)$.

A chemical makeup area is located on the second level beside the shielded canyon. Additional makeup tanks would need to be installed if WESF is used for sludge treatment. 
Figure 5-2. Layout of WESF First Floor

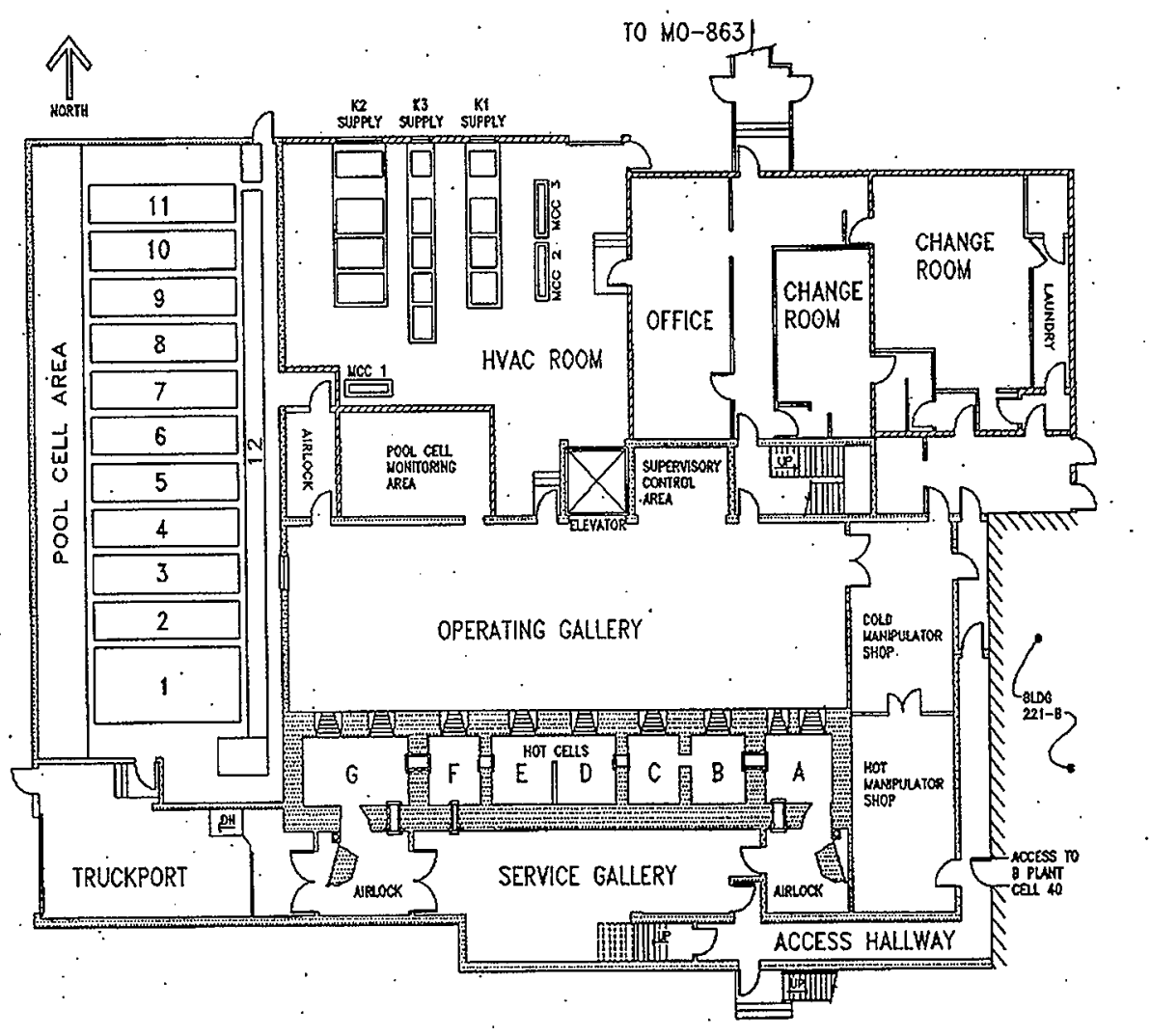


WESF also contains a truck bay for loading and unloading the cask used to ship Cs and $\mathrm{Sr}$ capsules. This truck bay could probably be used to load in sludge from the $\mathrm{K}$ Basins and load out treated sludge for transfer to the AW tank farm. A shielded line would need to be installed from the truck bay to one of the hot cells, or the sludge cask would need to be transferred into the canyon and remotely connected to a transfer line to one of the hot cells.

The WESF hot cells and canyon are primary confinement areas and are supplied and exhausted by the $\mathrm{K} 3$ ventilation system. Outside air is drawn into the canyon through filters. Part of the canyon air is drawn into the hot cells through chilled water coils and HEPA filters with the remaining air going directly from the canyon to the $\mathrm{K} 3$ final filter system. Each hot cell has two parallel inlet ducts from the canyon. The air is exhausted from each cell through two parallel outlet ducts with HEPA filters. The outlet ducts join a common duct leading to the final filters.

The final K3 filter system consists of two parallel filter housings. Each filter housing unit is located in a separate filter pit south of the WESF building. Normally one unit is operating while the other is on standby. Each filter housing contains a system of impingement vanes, moisture separators, heaters, a sump, and two banks of six HEPA filters. After passing through the HEPA filters, the air is exhausted to the stack through either one of two parallel fans. Failure of one exhaust fan automatically starts the off line fan. The K3 system also contains a backup steam jet in case neither exhaust fan is operable.

The K3 final filters are designed for remote replacement using a mobile crane. Wedge connectors at the inlet and outlet seal the filter housing to the ducting, but allow remote removal.

WESF is classified as a Hazards Category 2 facility. Since it contains essentially no fissile material, it is classified as an exempt facility for criticality control. The WESF hot cells, canyon, and $\mathrm{K} 3$ ventilation system are designed to withstand a 0.25 gravity design basis earthquake and are safety class structures (Covey, 1998).

\subsubsection{Canyon Facilities}

Most of the canyon facilities at Hanford have been deactivated and turned over to Bechtel Hanford Inc for surveillance and eventual decontamination and decommissioning. The only canyon facilities that have not been deactivated are T Plant and the 244-AR vault. Neither of these facilities was built to the current seismic criteria.

\subsection{4-AR Vault}

The AR Vault building is an old inactive canyon facility located near the 241-A Tank Farm. The AR Vault contains three cells. One smaller cell contains two 17,8001 (4700 
gal) tanks while each of the two larger cells contains one 162,750 l (43,000 gal) tank. The tanks are currently partially filled with legacy waste which would have to be removed before the facility could be used. There is also liquid in one of the cell sumps which most likely seeped in from outside the building. If this is the case, the vault cannot be used for secondary containment of hazardous waste. The two large cells in the AR Vault cannot be renovated for a new mission if it requires replacement of the tanks located in those cells. Part of the top of the cells overhangs the tanks and the cell below which makes it impossible to remove the tanks without demolishing the top of the cells. This by itself makes the AR Vault unsuitable for $\mathrm{K}$ Basin sludge processing.

\subsection{T Plant}

The T Plant canyon is one of the three original canyon facilities built in the 1940's to recover $\mathrm{Pu}$ from reactor fuel elements using the bismuth phosphate process. When the $\mathrm{T}$ Plant fuel reprocessing mission ended in 1956, the plant was converted to a decontamination and maintenance facility for failed canyon equipment. In addition to decontamination, the building has been used for repackaging and verification of waste.

The 221-T building consists of the canyon area, craneway, three galleries (operating, pipe, and electrical), and a headend area. The canyon area consists of 37 cells arranged in a single row running the length of the building as shown in Figure 5-3. Except for a few specialty cells, the cells are $5.4 \mathrm{~m}$ long $\times 4 \mathrm{~m}$ wide $\times 8.5 \mathrm{~m}$ deep $(17.67 \mathrm{ft} \times 13 \mathrm{ft} \times 28$ $\mathrm{ft}$ ). A shielded pipe trench and vent tunnel run the length of the building parallel to the cells. The cells and pipe trench are covered by shielded cover blocks that form the canyon deck. A cell drain header runs beneath the cells and drains into a tank in one of

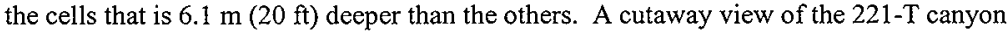
is shown in Figure 5-4. Equipment can be moved into and out of the canyon from a RR tunnel that enters the side of the canyon near the NE end. A horizontal rolling steel door can be used to isolate the RR tunnel from the canyon deck area. The cells, canyon deck, and $R R$ tunnel are serviced by a 45-ton bridge crane (down graded from 75 ton) that runs the length of the canyon. The crane cab is located in the craneway above the operating gallery and is shielded from the canyon by parapet wall. There is also a 10-ton crane that is normally operated from the canyon deck by use of a suspended control box that hangs from the crane assembly.

The headend section of $\mathrm{T}$ plant consists of the section of the building located on the opposite side of the RR tunnel from the remaining cells. A sheet metal wall separates the headend from the rest of the plant. The headend area consists of one large cell, a control room, laboratories, a change room, maintenance shop, and high bay work area. The large

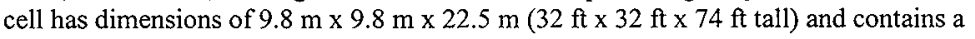
large containment vessel that extends from the bottom of the cell nearly to the roof the building. The headend area is used for waste verification and repackaging activities. 
HNF-4286, Rev. 0

Figure 5-3. I Plant Layout

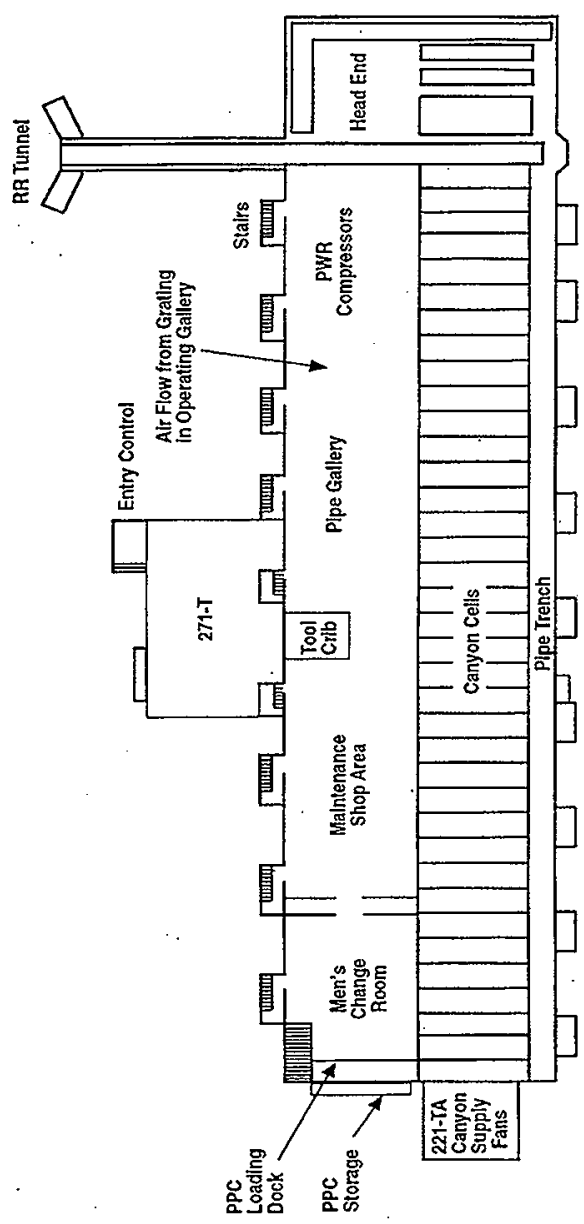


Figure 5-4. T Plant Cutaway

\section{T Plant Cutaway}

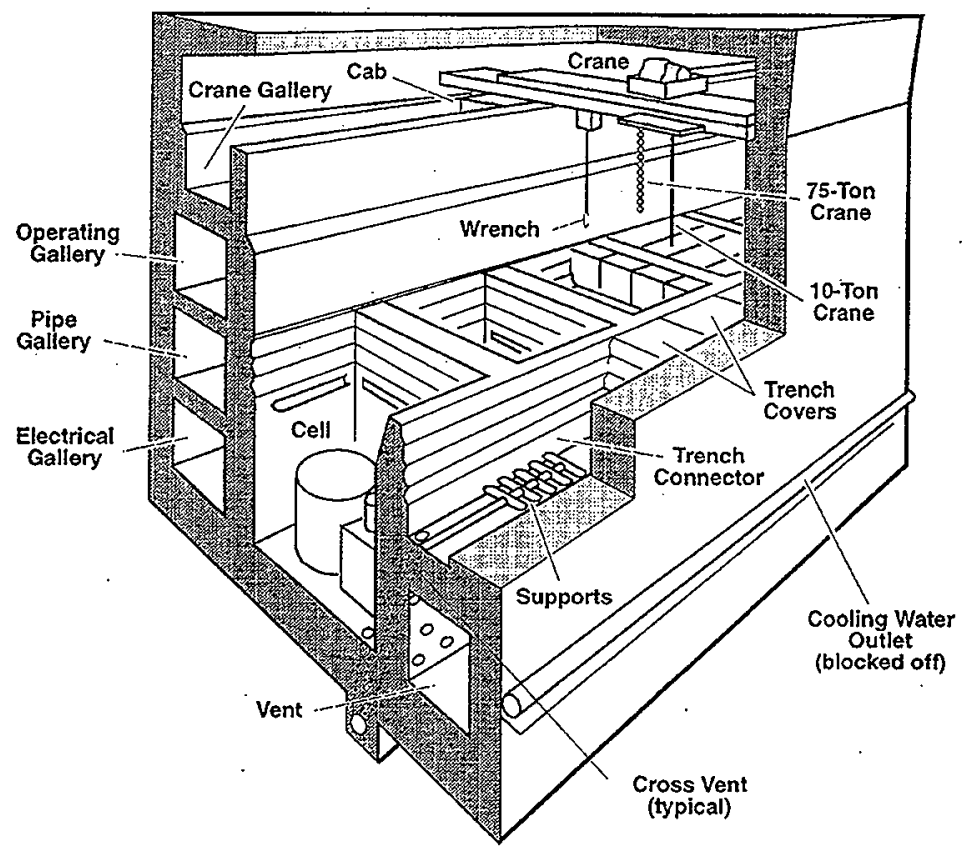

39312050.2

T PLANT
$3 / 94$ 
The three galleries run the length of 221-T on the west side of the canyon. The electrical gallery is located at the bottom level. It contains the main electrical lines, motor control centers, and the electrical distribution centers for the building. The pipe gallery is located above the electrical gallery at ground level and contains most of the non radioactive process and utility piping. The operating gallery is located above the pipe gallery and contains the control panels for the canyon equipment as well as offices for operations personnel

Currently T Plant is classified as a limited control nuclear facility due to the form of the fissionable material in the Shippingport PWR Core II blanket assemblies. There are no safety class or safety significant systems in T Plant. It is classified as a Hazard Category 3 facility.

All of the liquid waste is scheduled to be removed from the T plant canyon by the end of 1999. Currently the only definite future mission for the 221-T canyon is storage of the Shippingport fuel assemblies. However, the 221-T canyon is being considered for storage and/or processing of remote handled TRU wastes in the project management plan (PMP) for TPA milestone M-91.

\subsubsection{222-S Laboratory}

The 222-S Laboratory is a Hazard Category 3 nuclear facility and located south of the REDOX Plant in the 200 West Area. The 222-S Laboratory was originally constructed between 1950 and 1951 to the building codes and standards applicable at the time. Since 1951, the building has been modified to increase the original laboratory and office space. The modifications were designed and constructed to the applicable codes and standards current at the time the modifications were performed.

The 222-S laboratory provides analytical analysis for the Hanford Site. The 222-S Laboratory consists of the 222-S Building and auxiliary buildings. The 222-S Laboratory is an isolated facility and limited to $1 / 3$ of a critical mass of fissile material (Weaver, 1998). The radiological inventory control program ensures that the facility radionuclide inventory remains below quantities that would produce accident dose consequences exceeding those in the bounding accident scenario.

The 222-S Building is a two-story structure $111.5 \mathrm{~m}$ ( $366 \mathrm{ft}$ ) by $32.6 \mathrm{~m}(\mathrm{ft})$ wide that is divided into laboratory support spaces, office spaces, hot cells and supplemental services see Figure 5-5. The building is designed with its own waste handling and decontamination facilities, fire protection and alarm systems, ventilation system, and radiation monitoring system. The auxiliary buildings are used for ventilation and electrical services, storing bulk materials and handling and transferring waste to an onsite waste handling system. Administrative and offices buildings are located within the 222-S Laboratory. 
HNF-4286, Rev. 0

Figure 5-5. Layout of 222-S

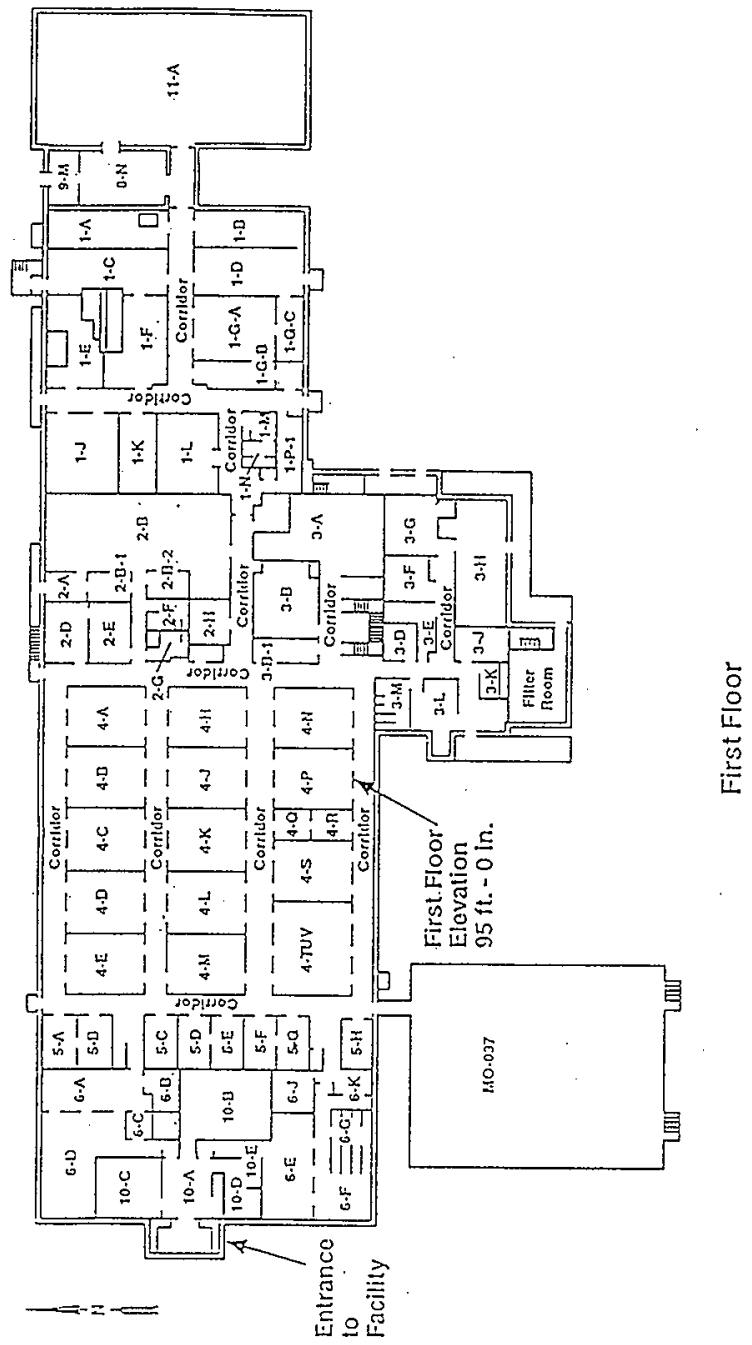


The first floor of the 222-S Building is divided into four general areas. The west section contains lunchroom, offices, and locker rooms. The west central section contains laboratories and service areas for work with radioactive and/or toxic materials. The east central section contains laboratories, hot cells, and service areas for working with radioactive samples. The east section contains the six new hot cells that are used for sample preparation and instrumentation analysis of high dose rate samples. A truck bay and crane are located between the east central and east sections. The crane is used to load and unload shielded containers (e.g. pigs, doorstops, sample carriers and core casks).

The partial basement includes tunnels, containing service piping and vacuum pumps, a counting room, instrument maintenance shop, and a scanning microscope laboratory.

The second floor includes the ventilation system supply fans, supply and exhaust ductwork, ventilation control room, glass shop, master slave manipulator repair shop and storage areas.

About $93 \mathrm{~m}^{2}\left(1,000 \mathrm{ft}^{2}\right)$ of floor space are reported to be available in the east section of the 222-S Laboratory (rooms $1-\mathrm{E}$ and $1-\mathrm{F}$ ). The $1-\mathrm{E}$ and $1-\mathrm{F}$ rooms contain three hot cells that have a total floor area of about $16 \mathrm{~m}^{2}\left(170 \mathrm{ft}^{2}\right)$. The hot cells are fabricated of carbon steel and covered with a corrosion resistant paint.

Six relatively new hot cells located in the 11-A room at the east end of 222-S have an additional $32.5 \mathrm{~m}^{2}\left(350 \mathrm{ft}^{2}\right)$ of floor space. However, these hot cells are scheduled to be used for analyzing tank farms characterization samples during the time that the sludge treatment facility is scheduled for operation. The largest of these cells is $3 \mathrm{~m} \mathrm{x} 6 \mathrm{~m} \mathrm{(10} \mathrm{ft}$ $\times 20 \mathrm{ft}$ ) with a dividing wall across the center. The five smaller cells have dimensions of $1.5 \mathrm{~m} \times 1.8 \mathrm{~m}(5 \mathrm{ft} \times 6 \mathrm{ft})$.

\subsection{EVALUATION OF THE EXISTING NUCLEAR FACILITIES}

\subsubsection{CVDF}

The CVDF contains five $9.1 \mathrm{~m} \times 18.3 \mathrm{~m} \times 7 \mathrm{~m}$ high (30' $\times 60^{\prime} \times 23^{\prime} \mathrm{h}$ ) processing bays. One bay will not be used for drying SNF and drying operations will be completed in a second bay prior to the scheduled start of construction on the sludge treatment facility. It is assumed that these two bays will be available for the sludge treatment facility. A third bay could possibly be used for a loadin/loadout truck bay, if the sludge transport cask can be left on the trailer and the loadin/loadout equipment that must be installed in this bay is minimal. This bay will be used for loading out contaminated water until fuel drying operations are complete so construction in this bay will be very limited, if it can be done at all, prior to the end of fuel drying.

If the CVDF is to be used for the sludge treatment facility, one $5.5 \mathrm{~m} \times 12.2 \mathrm{~m}\left(18^{\prime} \times 40^{\prime}\right)$ hot cell with $67 \mathrm{~m}^{2}\left(720 \mathrm{ft}^{2}\right)$ of space must be installed in one of the CVDF bays, or a 
smaller cell must be installed in each of the two bays that will be available. The two rectangular areas in the bays that are supported by $83 \mathrm{~cm}\left(2^{\prime} 9^{\prime \prime}\right)$ thick concrete footings have dimensions of $5.5 \mathrm{~m} \times 5.9 \mathrm{~m}\left(18^{\prime} \times 19.5^{\prime}\right)$ and $1.8 \mathrm{~m} \mathrm{x} 6.4 \mathrm{~m}\left(6^{\prime} \times 21^{\prime}\right)$ and are separated by $3.3 \mathrm{~m}\left(10^{\prime} 9^{\prime \prime}\right)$ of floor space that includes the floor sump. The concrete thickness between the footings ranges from $20.3 \mathrm{~cm}\left(8^{\prime \prime)}\right.$ where there is no footing at all to $86 \mathrm{~cm}\left(2^{\prime} 10^{\prime}\right)$ where part of the wall footing extends into this area.

Demolishing the existing CVDF floor where there are no footings so that a thicker base mat can be installed is not considered feasible while fuel drying operations are in progress in an adjacent bay. Pouring a new concrete base mat on top of the existing floor also is not considered feasible due to the height requirements for the processing equipment.

A steel hot cell with inside dimensions of $5 \mathrm{~m} \times 5.4 \mathrm{~m}$ (16' 4" $\left.\times 17^{\prime} 10^{\prime \prime}\right)$ and $25 \mathrm{~cm}$ (10in) thick walls and an area of $26.9 \mathrm{~m}^{2}\left(291 \mathrm{ft}^{2}\right)$ would fit on the large rectangle. If hot cells of this size are installed on the large rectangular footing in both available bays, the total hot cell space would be $54 \mathrm{~m}^{2}\left(582 \mathrm{ft}^{2}\right)$ compared to the $67 \mathrm{~m}^{2}\left(720 \mathrm{ft}^{2}\right)$ of hot cell space needed for sludge processing.

A steel hot cell covering both of the rectangles in one bay and the space in between would have inside dimensions of $5 \mathrm{~m} \times 10.5 \mathrm{~m}$ (16' 4" $\left.\times 34^{\prime} 7^{\prime \prime}\right)$ with a $25 \mathrm{~cm}(10 \mathrm{in})$ wall thickness. A hot cell of this size would have $52.4 \mathrm{~m}^{2}\left(564 \mathrm{ft}^{2}\right)$ of area compared to the estimated $67 \mathrm{~m}^{2}\left(720 \mathrm{ft}^{2}\right)$ of hot cell space that is needed for sludge processing. A $52.4 \mathrm{~m}^{2}\left(564 \mathrm{ft}^{2}\right)$ hot cell would need to be installed in one bay and a $14.5 \mathrm{~m}^{2}\left(156 \mathrm{ft}^{2}\right)$ hot cell in a second bay in order to get $67 \mathrm{~m}^{2}$ of hot cell space. The two hot cells would need to be connected by shielded piping. The hot cell space required for sludge treatment in the CVDF possibly could be reduced to $52.4 \mathrm{~m}^{2}$ by optimizing the equipment layout and/or performing some of the process steps at other facilities.

One way to reduce the hot cell space required for sludge treatment in the CVDF would be to separate the organic ion exchange resin from the sludge at the $\mathrm{K}$ Basins so the elutriation column and screens for resin separation would not need to be located in the hot cell. Another way to reduce the hot cell space required in the CVDF would be to locate the neutralization part of the process in a small facility located at the AW Tank Farm. The size of the hot cell could be reduced by $5-10 \%$ since it would not have to house the neutralization tank. The storage and makeup tanks for $\mathrm{NaOH}, \mathrm{NaNO}_{2}$, and $\mathrm{Fe}\left(\mathrm{NO}_{3}\right)_{3}$ which would be located in a cold area, also would not be needed at the CVDF. If the hot cell space requirement is reduced by optimizing the layout and locating part of the process at other facilities, a hot cell built over both footings in one bay of the CVDF might have adequate hot cell space for sludge processing.

A structural evaluation was performed to determine if the thickened footings could support a steel hot cell with inside dimensions of $5 \mathrm{~m} \mathrm{x} 10.5 \mathrm{~m}$ x $4.9\left(16^{\prime} 4\right.$ " x $34^{\prime} 7$ " $\mathrm{x}$ $\left.16^{\prime}\right)$ tall and a $25 \mathrm{~cm}$ (10") wall thickness (Ziada, 1999). The hot cell would cover both footings in one bay and the space in between. The hot cell would be anchored to the footings with anchor bolts around the perimeter of the cell. The evaluation assumed that 
the hot cell would have to withstand an earthquake response spectrum for a performance category P3 facility. Structural calculations showed that the footings would fail to support the hot cell in two areas. The large footing would crack along its centerline and the anchor bolts would not hold the cell in place. In order to anchor the hot cell, 1-in diameter bolts would need to be spaced 5.5 inches apart around the perimeter of the cell. However, the minimum spacing that the Hanford building code allows between 1 -in anchor bolts is 6 inches.

The HVAC system and the second floor mezzanine in the CVDF bays along with its supporting framework would need to be removed before the hot cells could be installed since some of the steel posts supporting the second floor mezzanine rest on the thickened slabs. A large overhead electrical conduit that crosses the end of the thickened slabs would need to be rerouted to make room for the hot cell. The top of the hot cells would be $5.2 \mathrm{~m}\left(17^{\prime}\right)$ above the floor which is higher than the level of the mezzanine. Part of one hot cell would have to go up to $6.7 \mathrm{~m}\left(22^{\prime}\right)$ high to provide enough elevation for the centrifuge, screens, and dissolver off gas condensers. A shielded sample cave and an air lock with equipment for replacing the elements in the cartridge filter would need to be located on top of one of the hot cells.

Installation of the hot cells would take up much of the usable space in the bays. There would be a $2.3 \mathrm{~m}$ (7.5') wide strip left on the west side of the hot cell, a $2.6 \mathrm{~m}\left(8.5^{\prime}\right)$ strip on the north side, and $5.3 \mathrm{~m}$ (17.5') between the cell and the rollup door on the east side. The sludge processing equipment that does not need to be in the hot cell would have to be installed in the remaining space or in an annex to the CVDF. This equipment includes the large tank for collecting the undissolved solids, grouting equipment, chemical makeup tanks, the off-gas system ( $\mathrm{NO}_{x}$ absorbers, mist eliminator, heater, $\mathrm{PCB}$ adsorber, HEPA filters), and the closed loop heating and cooling systems.

The large solids reception tank must hold all of the undissolved solids from the sludge processing campaign. It has been sized at $4.6 \mathrm{~m}(15.1 \mathrm{ft})$ in dia $\times 4.5 \mathrm{~m}(14.7 \mathrm{ft}) \mathrm{high}$. If a hot cell is installed in each of the two bays, the only space left for the solids tank is just inside the vehicle door in either of the bays. The grouting equipment would have to be squeezed into the space between the hot cell and the vehicle door in the other bay.

The $\mathrm{NO}_{\mathrm{x}}$ absorbers could be located on the north side of one of the hot cells with the mist eliminator, heater, PCB adsorber, and HEPA filters located on the second level between the hot cell and the vehicle door.

The CVDF primary and secondary chiller system could be used to provide cooling water to the sludge treatment system, if it has adequate capacity. The CVDF offices, change rooms, radiological control office, decontamination room, and lunchroom also could be used by the sludge treatment facility if it is installed in the CVDF. The CVDF stack, stack monitoring system, and part of the HVAC system also probably could be used by the sludge treatment facility. Additional HVAC equipment would need to be installed to control the airflow from the clean areas to the contaminated areas. 
Bulk chemical tanks for $\mathrm{HNO}_{3}, \mathrm{NaOH}$, and $\mathrm{NaNO}_{2}$ would need to be located outside the CVDF as would a grout batch plant. The tanks could be located any available place around the CVDF as long as the tanks and lines had secondary containment. The grout batch plant with a mechanical feed system would need to be located as close as possible. Possibly, it could be skid mounted and set just outside the vehicle door just prior to the start of cold testing.

A closed loop steam or hot water system, and a control room would need to be installed in a CVDF annex.

The total dispersable inventory in the CVDF (Pili-Vincens, 1998) is assumed to be the particulate loading in four MCO's (one "maximum" $\mathrm{MCO}$ and three others) and the contents of the process water conditioning system. The total loading is assumed to be $555 \mathrm{~kg}$ particulate. The FSAR has lowered the amount of particulate loading in the maximum MCO to $176 \mathrm{~kg}$ and is basing the final hazard classification on the amount of fuel available for release in a single accident - the maximum MCO particulate loading. The sludge treatment facility will probably contain at least four batches of sludge- one in lag storage awaiting processing, two in process, and one in lag storage awaiting transfer to Tank Farms. This is a total of $640 \mathrm{~kg}$ particulate, which could be mostly fuel if it is fuel wash sludge. The CVDF is a general service structure, even though it is hazard category 2 , because the safety class confinement function is mostly provided by the $\mathrm{MCO} / \mathrm{cask}$. This approach would not be practical for the sludge treatment system because of the number of process vessels and pumps to be included in the chemical processes. If it is assumed that the vessels do not provide safety class confinement, the facility will have to provide it. It is assumed that there are four batches of material in the facility - one batch in lag storage, one batch in the dissolver feed tank, one batch in the dissolver, and one batch of treated sludge awaiting shipment. If it is assumed that (in an earthquake) all vessels spill their contents and that the fuel in the two batches upstream of the dissolver catches fire, the total amount of fuel released could be more than $300 \mathrm{gm}$ (assuming a $0.1 \%$ fire release fraction). According to the current CVDF SAR, the amount of fuel released to require safety class systems to prevent or mitigate the release is approximately $95 \mathrm{gm}$. Therefore, the sludge treatment hot cell and ventilation system would need to be safety class systems.

The CVDF ventilation system is not safety class and it would take a major upgrade to make it safety class including replacement of the fans, instrumentation, controls, and electrical feed. A safety class emergency generator would be needed to ensure power is available to operate the ventilation fans if the main power is lost.

If the sludge treatment facility is installed in spare bays of the CVDF, construction will begin while the CVDF is still operating. The CVDF SAR will need to be changed to allow construction activity in one or two bays of the CVDF while drying operations are in progress in the other bays.

Construction activities in the CVDF will be controlled by the job control system which will decrease productivity of construction forces when compared to a standalone facility. 
All construction work will have to go through the planning process and be approved by operations management before the work can start. Pre-job planning meetings will be required for the craft people and supporting workers.

The operating bays in the CVDF must be physically isolated from the bays where construction work is in progress for security reasons. Some of the equipment that is needed to operate the vacuum drying units in the operating bays will be located in the bays needed for installation of the sludge treatment facility. This equipment includes a water transfer line and some safety class instrumentation. The water line will be used once per day to transfer contaminated water from one of the operating bays through the bays that will be used for the sludge treatment facility to the water treatment equipment. The dose rate that will be present at the surface of this line during water transfers is not known, but is expected to be low. The safety class instrumentation will need to be protected to ensure that construction activities do not disable a safety class system.

One MCO transporter will enter the CVDF and another one will leave once per day during the period scheduled for construction of the sludge treatment facility. There may be some interference between MCO transporters and construction vehicles, but this is not considered a serious problem.

\subsubsection{WESF}

The total floor area in the five WESF hot cells that are available for a new mission is 33 $\mathrm{m}^{2}\left(352 \mathrm{ft}^{2}\right)$. However, one of the smaller cells or half of the $\mathrm{D} / \mathrm{E}$ cell will be needed to store the old equipment that is presently in the cells. The dose rate from this equipment is too high to remove it for burial. This will reduce the available space for new equipment to $27 \mathrm{~m}^{2}\left(288 \mathrm{ft}^{2}\right)$. This is only $40 \%$ of the $67 \mathrm{~m}^{2}\left(720 \mathrm{ft}^{2}\right)$ in the preliminary hot cell layout for the sludge treatment facility. Approximately $40 \mathrm{~m}^{2}\left(432 \mathrm{ft}^{2}\right)$ of additional hot cell space will need to be added to WESF if it is going to be used for the sludge treatment facility. The WESF hot cells are about 13 feet tall which is not enough height for the screens, centrifuge, and dissolver off gas condensers of the sludge treatment facility. Part of the new hot cell space that would need to be added to WESF would have to be about $5.9 \mathrm{~m}(19.5 \mathrm{ft})$ tall to provide enough height for these pieces of equipment. The $50-\mathrm{m}^{3}$ solids collection tank would have to be located in an addition to WESF. The grouting equipment for the cartridge filters probably could be located in the canyon or some other place inside WESF.

A chemical makeup area is located on the second level above the operating gallery and beside the shielded canyon. This area could be used for a chemical makeup area for sludge treatment. Additional makeup tanks would need to be installed if WESF is used for sludge treatment. Bulk tanks for $\mathrm{HNO}_{3}, \mathrm{NaOH}$, and $\mathrm{NaNO}_{2}$ would need to be added outside the building.

WESF contains a truck bay for loading and unloading the casks used to ship $\mathrm{Cs}$ and $\mathrm{Sr}$ capsules. This truck bay could probably be used to load in sludge from the $\mathrm{K}$ Basins and 
load out treated sludge for transfer to the AW tank farm. The MCO cask is too tall to fit into the truck bay so it could not be used for sludge shipments to WESF. Shielded loadin and loadout lines would need to be installed from the truck bay through the service gallery to the hot cells.

The only place inside WESF that could possibly be used to build additional hot cell space is in the operating gallery opposite the existing hot cells. Unused instrument panels in this area would have to be removed. There are two major problems with building a hot cell in this area. The first is that the concrete floor in this area probably is not thick enough to support the weight of a hot cell. The second problem is that there would be no crane above this area to access the cell cover blocks. The chemical makeup area and transmitter rooms are located above this area. Modifying the building to install a crane in this area is not considered feasible.

Installing additional hot cell space in an addition to WESF was also considered. An addition to WESF would have to be built on the south or west sides of the building. The hot cell in the addition would need to be connected to the existing hot cells by shielded piping. A new ventilation system would need to be built for the new hot cells since the existing ventilation system could not handle the additional flow needed for the new hot cell. This would also be the case if a new hot cell could be built inside the WESF facility.

The 212-B Cask Transfer building located approximately $100 \mathrm{~m} \mathrm{SE}$ of WESF contains a $3.3 \mathrm{~m} \times 3.3 \mathrm{~m}\left(11^{\prime} \times 1 l^{\prime}\right)$ hot cell (121 $\mathrm{ft}^{2}$ area) that could be used for part of the sludge treatment facility if a shielded line is installed to connect the two buildings. The hot cell in 212-B is clean enough to allow manned entry for equipment installation. The 212- B building also contains a truck bay and bridge crane for moving casks from the truck bay to the hot cell. The 212-B building has been deactivated and turned over to $\mathrm{BHI}$ for eventual decontamination and decommissioning. All of the utilities to the building were isolated as part of the deactivation. However, utilities could be restored to the building if it were to be used for a new mission.

If the hot cell space in 212-B is added to the available hot cell space in WESF the total comes to $38 \mathrm{~m}^{2}\left(409 \mathrm{ft}^{2}\right)$. This is still only $57 \%$ of the hot cell space needed for the baseline sludge treatment process.

\subsubsection{4-AR Unloading Facility}

The 204-AR facility is too small to house a sludge treatment facility and there is not room to build a sludge treatment facility next to it.

An evaluation of the 204-AR facility for unloading sludge and transferring it to AW-105 was completed in 1995 (Wallace, 1995). The evaluation concluded that the transfer pump would have to be upgraded and shielding installed at the pumping station to transfer sludge through the line to AW-105. The route from $204 \mathrm{AR}$ to $\mathrm{AW}-105$ goes through several valve pits which increases the probability of solids settling out in the line. TWRS uses 204-AR to unload waste from several facilities and transfer it through this 
line to double shell tanks. Since there are no alternate routes for transferring waste from 204-AR to the double shell tanks, TWRS has been unwilling to allow the use of this line for transfer of K Basin sludge into AW-105 (Fowler, 1995). The 204-AR facility could be used for unloading neutralized sludge if a new pump and dedicated transfer line to AW-105 are installed.

A design was completed for a new unloading station that would be located directly west of tank AW-105 within the tank farm perimeter fence. This unloading station was designed to transfer sludge directly from the transport container through a new dedicated line to AW-105 (H-14-100727).

The 204-AR facility was evaluated to determine if it could be used to neutralize an acidic sludge solution if the rest of the sludge treatment process was done elsewhere. The inline neutralization system in 204-AR could not be used for sludge neutralization due to the high acid concentration ( $4 \underline{\mathrm{M}})$ in the treated sludge and the heat that would be generated by neutralization. The 56801 (1500 gallon) collection tank does not have an agitator and does not have a large enough flange to install an agitator so it could not be used for sludge neutralization. There is not enough space inside the shielded portion of 204-AR to install a neutralization tank large enough to hold a batch of neutralized sludge. The sludge streams require up to 14601 ( 385 gallons) of $\mathrm{NaOH}$ and 10201 ( 270 gallons) of $\mathrm{NaNO}_{2}$ per batch of treated sludge (Westra, 1998). If these tanks were used for neutralization, they would need to be refilled for every batch. There is a $56801(1500$ gallon) $\mathrm{NaOH}$ storage tank that could be used to refill the $\mathrm{NaOH}$ neutralization tank. It holds enough $\mathrm{NaOH}$ to neutralize 3 batches of sludge. There is no storage tank for $\mathrm{NaNO}_{2}$.

In order to use the 204-AR unloading facility for sludge neutralization, a shielded neutralization tank with an agitator and cooling capability would need to be installed in an annex to the building. Other equipment that would be needed include: Storage tanks for $\mathrm{NaOH}$ and $\mathrm{NaNO}_{2}$ that would hold at least 5000 gallons, pumps to transfer the $\mathrm{NaOH}$ and $\mathrm{NaNO}_{2}$ to the neutralization tank, a pump to transfer the neutralized sludge to AW105 , interconnecting lines between the unloading station and the neutralization tank, and instrumentation to control the neutralization process. The existing 204-AR ventilation system and floor drain system could be used.

\subsubsection{4-AR Vault}

The 244-AR Vauit is not considered suitable for a sludge processing facility since it is in a poor state of repair, does not meet current standards (unencased transfer lines, questionable secondary containment for vessels, questionable seismic qualification), would be difficult to modify, and would require a major clean up effort before construction could begin. Part of the top of the cells overhangs the tanks and the cell below which makes it impossible to remove the tanks without demolishing the top of the cells. This by itself makes the AR Vault unsuitable for $\mathrm{K}$ Basin sludge processing. 


\subsubsection{T Plant}

Most of the T Plant canyon cells are $5.4 \mathrm{~m} \times 4 \mathrm{~m}(17.67 \mathrm{ft} \times 13 \mathrm{ft})$ with a cross-sectional area of $21 \mathrm{~m}^{2}\left(230 \mathrm{ft}^{2}\right)$. The large headend cell is $9.75 \mathrm{~m} \mathrm{x} 9.75 \mathrm{~m}(32 \mathrm{ft} \times 32 \mathrm{ft})$ with a cross-sectional area of $95 \mathrm{~m}^{2}\left(1024 \mathrm{ft}^{2}\right)$. The sludge processing facility requires at least $67 \mathrm{~m}^{2}\left(720 \mathrm{ft}^{2}\right)$ of cell space according to the layout prepared for the alternatives study (Pearce, 1999). At least four canyon cells or the large headend cell would be required to install the sludge processing hot cell equipment. Before canyon cells could be used, any existing equipment would need to be removed. This equipment would either need to be placed in other canyon cells, on the canyon deck, or decontaminated and placed into burial boxes for disposal at the Central Waste Complex. Several cells are empty or nearly empty so equipment disposal is not considered a major problem. Stainless steel liners with sumps, or an epoxy liner, would need to be installed in the cells to provide secondary containment.

The large solids collection tank for the sludge treatment process has been sized at 50,000 $1(13,200 \mathrm{gal})$ so it would take up an additional cell if it is installed in the canyon. An existing tank possibly could be used if it could be decontaminated to low enough levels. The tank would need to be quite clean since the TRU and Cs-137 concentration in the grouted solids must be low enough to meet ERDF acceptance criteria. The solids grouting equipment could be located on the canyon deck where it could be contact maintained.

An alternative would be to place the solids collection tank and grouting equipment outside T Plant within a lightly shielded contact maintenance annex. This would require core drills through the canyon and pipe trench wall to install a line for transferring the solids from the centrifuge to the solids collection tank. Since the cells are below ground level, the solids could not be transferred from the centrifuge to the solids tank by gravity unless the solids tank is located partly below grade.

The large ( $32 \mathrm{ft} \times 32 \mathrm{ft}$ ) cell in the T Plant headend is large enough that all of the sludge treatment equipment that requires heavy shielding could be installed in it. The solids collection tank would need to be installed in another cell or in a lightly shielded facility adjacent to $T$ Plant. The large containment vessel currently in the headend cell would need to be cut up for disposal as waste. The isolation wall between the headend area and the RR tunnel would need to be removed so that the canyon crane could move sludge transport casks into and out of the headend area. The crane could also be used to bring equipment into the headend cell during construction of the sludge treatment facility.

The sludge could be brought into T Plant through the RR tunnel by truck trailer. The vehicle ramp down to the $R R$ tunnel will be upgraded to handle the MCO cask transporter as part of the project to transfer the Shippingport fuel from T Plant to the Canister Storage Building (LATA/BNFL, 1996). The canyon crane could be used to move the sludge transport cask from the transport vehicle to the canyon deck. Then a transfer line and power supply would need to be attached to the transfer cask so that the sludge could be pumped from the cask to the lag storage vessel located in one of the cells. 
After pumping out the sludge and rinsing the cask, the transfer line and power supply would be disconnected from the cask. Then the cask would be decontaminated as necessary and transferred from the canyon deck to the transport vehicle.

The treated sludge could be brought out by reversing the steps used to bring in the sludge. The volume of treated sludge transferred out to AW-105 would be about 6 times larger than the volume of sludge brought in. An evaluation of sludge transport concepts (Klem, 1999) concluded that from a transportation standpoint the lowest cost alternative is to locate the sludge treatment facility close enough to tank AW-105 that the treated sludge can be transferred through a short pipe to the tank. If the treated sludge cannot be pumped from the treatment facility to a waste tank, it will need to be transferred both to and from the facility using a shielded cask. This would be the case for T Plant. The MCO cask could be used to transport the sludge from the K Basins to the treatment facility, but a larger cask would be needed to transport the larger volume of treated sludge to the waste tank.

Currently T Plant is a limited control facility due to the form of the fissionable material in the Shippingport PWR Core II fuel stored in one of the cells. It would have to be changed to a fissile facility if used for $\mathrm{K}$ Basin sludge processing. T Plant is currently a hazards category 3 facility. It would have to be changed to a hazards category 2 facility for sludge processing. Since T Plant was not built to today's seismic standards, a new seismic analysis would be required before sludge processing could be done there. This seismic analysis will have to take into account the dispersible source term that will be present in the sludge processing equipment (enough to make it a Hazards Category 2 facility). Currently $T$ Plant has a very low dispersible source term so the T Plant safety basis documentation would require major revisions.

Other potential problems are 1) keeping the canyon crane operating, and 2) troubleshooting and repairing electrical heads which have not been used for many years,

Several of the old canyon processing facilities at Hanford (T Plant, B Plant, and PUREX) have been evaluated for new missions in the past 15 years. In the 1980s, there was a project initiated to install pre-treatment equipment for tank farm waste in B Plant. However, in 1990, it was decided that B Plant could not meet the modern safety, seismic, and containment criteria so it was eliminated from consideration as the site's pretreatment facility. Recently Hanford's old canyon facilities were considered for disposal of low activity vitrified waste as part of the Alternate Generation Analyses, but were not recommended partly due to uncertainties about canyon conditions and regulatory compliance. The PUREX plant was also considered for interim storage of high level vitrified waste as part of the Alternate Generation Analyses, but not recommended. The seismic adequacy and structural suitability of PUREX for a long-term mission were among the most important issues in the decision.

T Plant is the oldest processing facility in the 200 areas (over 50 years old) so it would be risky to assume that it can meet the current seismic and safety class containment criteria required to use it for treatment of the $\mathrm{K}$ Basin sludge without major upgrades. 
The $T$ Plant canyon deck is being considered for the site of a facility to process the remote handled TRU waste currently stored in the $200 \mathrm{~W}$ area (TPA milestone M91). If the T Plant structure and documentation are upgraded to process remote handled TRU, then most of the upgrades that would be needed to treat the $\mathrm{K}$ Basin sludge will already be done. The treatment equipment and control system would need to be installed, but the building structure and shielding would be in place. After the sludge treatment campaign is completed, the sludge treatment equipment probably could be used to process some of the remote handled TRU waste.

The difference between considering T Plant for sludge treatment and the evaluations of other canyon facilities for future missions is that the canyon deck and pool cell are being considered in T Plant while only the canyon cells were considered for future missions in most of the other studies. Upgrading cells to ensure secondary containment for hazardous waste is more difficult than installing new equipment with secondary containment on the canyon deck.

If the burden of T Plant upgrades to process sludge fell entirely to the Spent Nuclear Fuel Project, the cost might equal or exceed the cost of a new stand alone facility. The extent of the needed upgrades are as yet unknown, but this assessment is made based upon needed improvement to other similar facilities for similar missions. If $T$ Plant is considered for an RH TRU mission, and K Basin sludge could be processed with it as part of a shared mission and managed as RH TRU waste rather than go to TWRS, then T Plant appears to be a viable site for sludge treatment.

\subsubsection{2-S Laboratory}

The 222-S laboratory is not considered suitable for a sludge treatment facility since the available hot cell space $\left(16 \mathrm{~m}^{2}\right.$ vs $\left.67 \mathrm{~m}^{2}\right)$ and floor space $\left(93 \mathrm{~m}^{2}\right.$ vs $\left.1020 \mathrm{~m}^{2}\right)$ do not meet requirements. Even if the six newer hot cells in the 11-A room could be used, there still would only be a total of $48 \mathrm{~m}^{2}$ of hot cell space in the 222-S laboratory compared to the $67 \mathrm{~m}^{2}$ needed for the sludge treatment facility. The six hot cells in the 11-A room are scheduled to be used for analyzing tank farm characterization samples at the same time that the sludge treatment facility is scheduled to be in operation. If the hot cells are used for sludge treatment instead of tank farm characterization sample analysis, it could cause a delay in the tank farm privatization schedule. Another thing that complicates using the six hot cells in the 11-A room as well as the hot cells in the 1-E and 1-F rooms is that the rooms are physically separated from each other by three other rooms. In order to use the cells in the two different areas for sludge processing, at least one shielded process line would need to be installed to allow transfers between the separated hot cell areas.

There are several other things that make the 222-S laboratory unsuitable for a sludge treatment facility. The shielding windows on the hot cells do not provide enough shielding from the radiation dose that would be present if $\mathrm{K}$ Basin canister and fuel wash sludge is brought into the hot cells. The crane that is used to bring sample casks into the 
1-E and $1-F$ hot cells does not have adequate capacity to lift the heavy cask that will be needed to transport $\mathrm{K}$ Basin sludge. The sludge could be pumped from the cask to the hot cells though a shielded line, but no such line exists.

The 222-S laboratory is a currently a Hazard Category 3 facility, but would need to be upgraded to a Hazard Category 2 facility for sludge treatment. A criticality alarm system would need to be installed. The building structure would need to be upgraded to meet current seismic criteria. 


\subsection{RECOMMENDATION FOR USE OF EXISTING FACILITIES}

\subsubsection{Development Criteria and Evaluation for Existing Facilities}

The existing facilities described in sections 5.3 and 5.4 were compared qualitatively using the criteria described in section 5.2. The comparison was done by preparing the matrix shown in Table 5-1.

Table 5-1. Selection Criteria for Sludge Treatment in Existing Facility (Sheet 1)

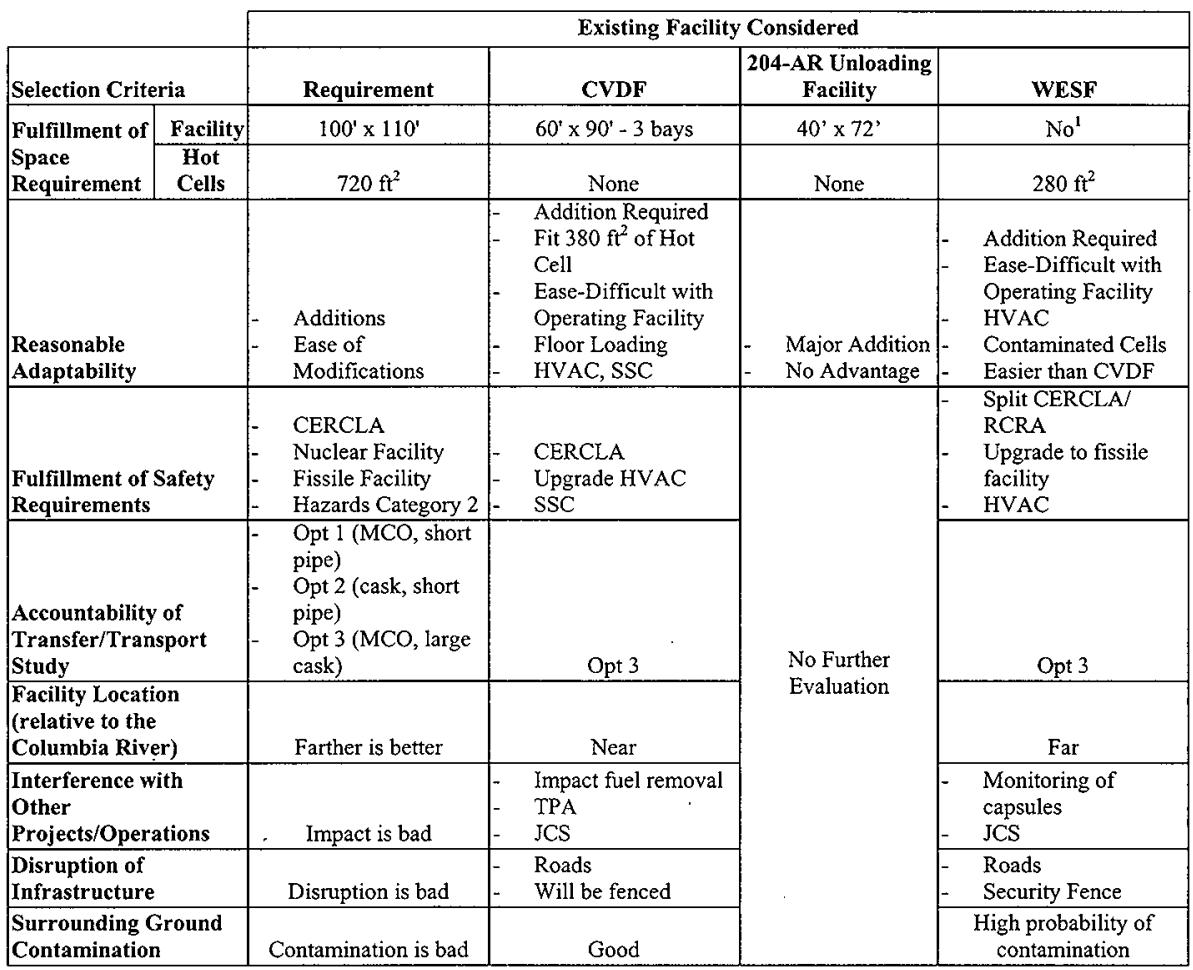


Table 5-1. Selection Criteria for Sludge Treatment in Existing Facility

(Sheet 2)

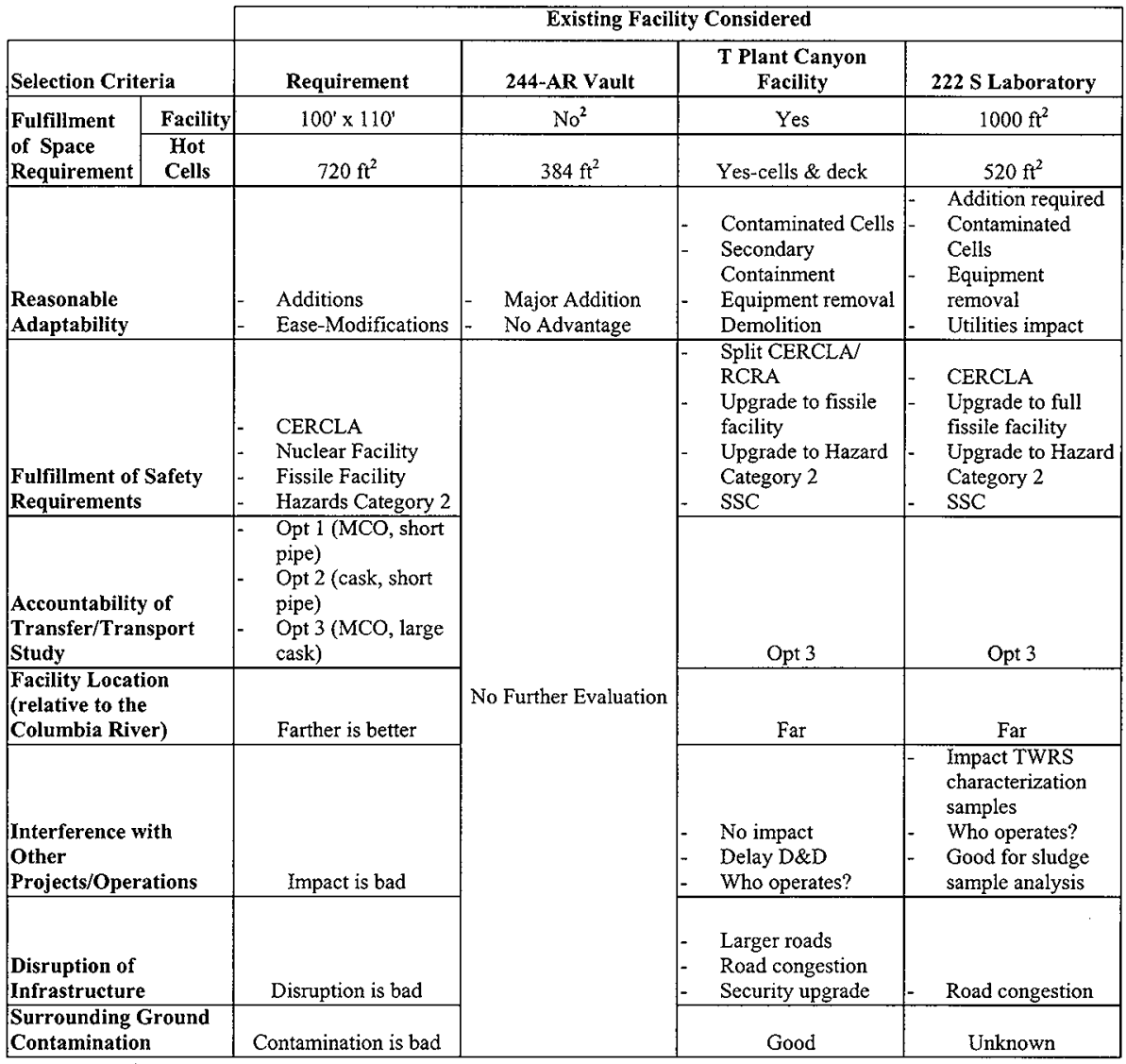

'Off-gas equipment/solids tank

${ }^{2}$ Upgrade ventilation system/addition of $9000 \mathrm{ft}^{2}$ for facility and $336 \mathrm{ft}^{2}$ for hot cell 
The only existing facility evaluated in this study that has enough space to install treatment equipment for $\mathrm{K}$ Basin sludge is T Plant. However, selecting T Plant as the site for sludge treatment would be risky since it is an old plant and it is questionable whether it will meet current seismic criteria for a Hazards Category 2 facility without costly upgrades. If $\mathrm{T}$ Plant is going to be upgraded to meet current seismic criteria as part of the remote handled TRU waste treatment project (TPA milestone M91), then it will be an acceptable site for $\mathrm{K}$ Basin sludge treatment.

The CVDF is not recommended as the site for sludge treatment since it does not have enough space for sludge treatment equipment, does not have a safety class containment system, and the floor slabs in the process bays are not thick enough to support a shielded cell.

The reasons for recommending or not recommending the existing facilities are described below.

\subsubsection{CVDF}

The CVDF is not recommended as a site for the sludge treatment facility for the following reasons:

a) CVDF offers no shielded space for the treatment process.

b) There is not sufficient space to house all of the sludge processing equipment in the two CVDF bays that will be available.

c) The floor footings designed to support the MCO cask and trailer are not thick enough to support the weight of a hot cell needed for sludge treatment.

d) The process vent system and electrical supply will need to be upgraded to safety class equipment

e) The addition of space and installment of the process would interfere with the ongoing operations of fuel removal.

f) CVDF is located in the $100 \mathrm{~K}$ area, which is undesirable due to its proximity to the Columbia River.

g) CVDF does not satisfy the short pipe criteria, which would increase costs due to shipping the sludge to the facility via cask or long pipe.

\subsubsection{WESF}

The WESF hot cells are not recommended as a site for the sludge treatment facility for the following reasons:

a) The hot cells do not have adequate space to hold all of the sludge treatment equipment that requires heavy shielding. If additional hot cells are built, a new ventilation system will be required because the existing ventilation system does not have the capacity to handle the additional off-gas flow that would be needed for the new hot cells. 
b) The existing off-gas system for the WESF hot cells is not designed for alpha containment.

c) All of the available WESF hot cells except A Cell are contaminated with Cs-137 and Sr-90 to the point that equipment removal and installation must be done remotely with the canyon crane and manipulators.

d) The surrounding area has a high probability of contamination, which would be highly undesirable for an addition to the facility.

e) The MCO casks could not be used to ship sludge to WESF since the cask is too tall to fit into the WESF truck port

\subsubsection{4-AR Unloading Facility}

The AR Unloading Facility is not recommended as a site for the sludge treatment facility because it has insufficient space to house the process equipment with no hot cell space. This facility would require major additions and carries no advantage, therefore it is not considered a viable option.

\subsubsection{T Plant}

T Plant is an acceptable site for the sludge treatment facility if the plant is going to be upgraded to meet current seismic criteria for a Hazards Category 2 facility. However, since T Plant is an old facility that was built over 50 years ago, it is risky to assume that it will be less costly to upgrade T Plant to meet current seismic criteria than to build a new facility. If the burden of T Plant upgrades to process sludge fell entirely to the Spent Nuclear Fuel Project, the cost might equal or exceed the cost of a new standalone facility. The extent of the needed upgrades are as yet unknown, but this assessment is made based upon needed improvement to other similar facilities for similar missions. If $\mathrm{T}$ Plant is considered for an RH TRU mission, and K Basin sludge could be processed with it as part of a shared mission and managed as RH TRU waste rather than go to TWRS, then T Plant appears to be a viable site for sludge treatment.

T Plant is considered an acceptable location for the sludge treatment facility for the following reasons:

a) T Plant canyon cells can be lined if necessary to meet current RCRA criteria for secondary containment of hazardous waste.

b) T Plant has adequate shielded space in the headend and/or canyon to house the sludge treatment equipment.

c) T Plant roads will be upgraded as necessary to handle the MCO cask transporter as part of the project to move the Shippingport fuel out of the pool cell.

d) The T Plant RR tunnel and canyon crane can be used to move a sludge transfer cask from a transport vehicle into the canyon or headend area.

e) If the sludge treatment facility is installed in T Plant, it probably could be used to process some of the remote handled TRU waste after the sludge treatment campaign is completed. 
An evaluation of sludge transport concepts (Klem, 1999) concluded that from a transportation standpoint the lowest cost alternative is to locate the sludge treatment facility close enough to tank AW-105 that the treated sludge can be transferred through a short pipe to the tank. If the sludge treatment facility is located in T Plant, the treated sludge will need to be transferred both to and from the facility using a shielded cask. The MCO cask could be used to transport the sludge from the $\mathrm{K}$ Basins to the treatment facility, but a larger cask would be needed to transport the larger volume of treated sludge to the waste tank. Sludge transportation costs will be substantially larger for sludge treatment in T Plant compared to a new standalone facility at AW Tank Farm.

\subsubsection{4-AR Vault}

The 244-AR Vault is not recommended as a site for the sludge treatment facility for the following reasons:

a) The 244-AR Vault does not meet existing criteria for secondary containment.

b) The ventilation system would have to be upgraded to meet the off-gas flow capacity requirements. It would also have to be upgraded to safety class equipment.

c) This facility has insufficient space to house the process equipment with only one cell that could be renovated. It would require a major addition and carries no advantage, therefore it is not considered a viable option

\subsubsection{S Laboratory}

The $222 \mathrm{~S}$ Laboratory is not recommended as a site for the sludge treatment facility for the following reasons:

a) The $222 \mathrm{~S}$ Laboratory has insufficient building space as well as insufficient hot cell space.

b) The laboratory hot cells are contaminated.

c) There would be an impact on the Tank Waste Remediation System (TWRS) characterization sampling that is already planned to take place in the new hot cell space in $222 \mathrm{~S}$.

d) Insufficient crane capacity for the large cask needed for sludge transport

e) Lack of adequate access for sludge transfer to the hot cells.

f) Insufficient shielding in the hot cell windows 
HNF-4286, Rev. 0

\section{CONSIDERATION OF A NEW STAND-ALONE NUCLEAR FACILITY}

\subsection{MINIMUM SITE REQUIREMENTS}

\subsubsection{SPACE}

As mentioned in Section 4, the processing building for a stand-alone facility would be approximately $1020 \mathrm{~m}^{2}\left(11,000 \mathrm{ft}^{2}\right)$, while the attached office and change room annex would be approximately $280 \mathrm{~m}^{2}\left(3000 \mathrm{ft}^{2}\right)$. According to the Hanford Real Estate Department, when locating land for a new facility, the space requirement should be at least doubled. This takes into account the construction laydown area, parking areas, and also gives some design leeway in case of pre-existing cables or structures that may not be portable. This results in an area requirement of approximately $2600 \mathrm{~m}^{2}\left(28,000 \mathrm{ft}^{2}\right)$ encompassing both processing building and office annex.

\subsubsection{ACCESS}

Space for parking of personal automobiles and government vehicles will be required. Since multiple shifts will be utilized enough parking will be required for two shifts plus support personnel. An estimated 80 parking spaces will be required. Also as many as three sludge transport systems could be at the facility. Parking for three semi-truck trailers inside the security area will be needed. Delivery of chemicals by site delivery trucks will also be required. The roads will have to withstand the shipment of 215 batches of sludge on the sludge transporters that will weight close to the 100,000 pound GVW load limit.

\subsubsection{UTILITIES AND INFRASTRUCTURE}

KVA power supply will be required to provide power to the facility plus emergency backup power will be required for certain safety systems. Diesel generators may be used for emergency backup power. Potable water, process water, and firewater will be required. Sanitary waste system will be required during construction and operation of the facility. Fire protection will be required from the Hanford fire Department.

\subsection{CRITERIA FOR SITE SELECTION}

All new stand-alone facilities will have certain criteria that they will be compared against. This comparison will determine whether or not the site is an acceptable location for the sludge treatment. The criteria that will be included in this examination are as follows:

- The site should take into account transfer/transport study.

- The $200 \mathrm{E}$ area is preferred (less volume to transport via cask).

- It is better to pump than to move via cask.

- The site would be better off away from the river. 
- There should be no underground obstructions on the considered site.

- There should be enough space to fulfill the space requirement.

- The proposed site should not interfere with other projects, operating facilities, or ongoing operations.

- The site should not disrupt existing infrastructure.

- The site should consider access to utilities.

- There should be no ground contamination on the proposed site (prior spills or disposal).

\subsection{POTENTIAL SITIES IN $100 \mathrm{~K}$ AREA}

A stand-alone facility at the $100 \mathrm{~K}$ Area would be a new building so it would be built to meet current safety standards.

If a location is chosen where there is no surface or underground contamination, there should be no additional radiation exposure to workers during construction of the facility. If the sludge is transferred from the basins to the treatment facility by pipeline, the pipeline tie-in at the basins will have to be done in a radiation field. Construction of an off-load facility at the AW Tank Farm also will involve some radiation exposure to workers.

See Figure 6-1 for a map of the potential site in the $100 \mathrm{~K}$ Basins. Sites are identified as Site A, Site B, Site C, Site D, Site E, Site G, Site J, Site K, and Site H. The Site marked Site $F$ is the CVDF site and in included in the existing facilities.

\subsection{POTENTIAL SITES IN 200 EAST AREA}

A stand-alone facility at the AW Tank Farm would be a new building so it would be built to meet current safety standards.

If a location is chosen where there is no surface or underground contamination, there should be no radiation exposure to workers during construction of the facility. However, tie-in of the transfer line from the facility to tank AW-105 will probably involve some radiation exposure to workers. See Figure 6-2 for a map of the potential sites in the AW Tank Farm area. Sites are identified as Site M, Site N, Site P, Site Q, and Site R. 


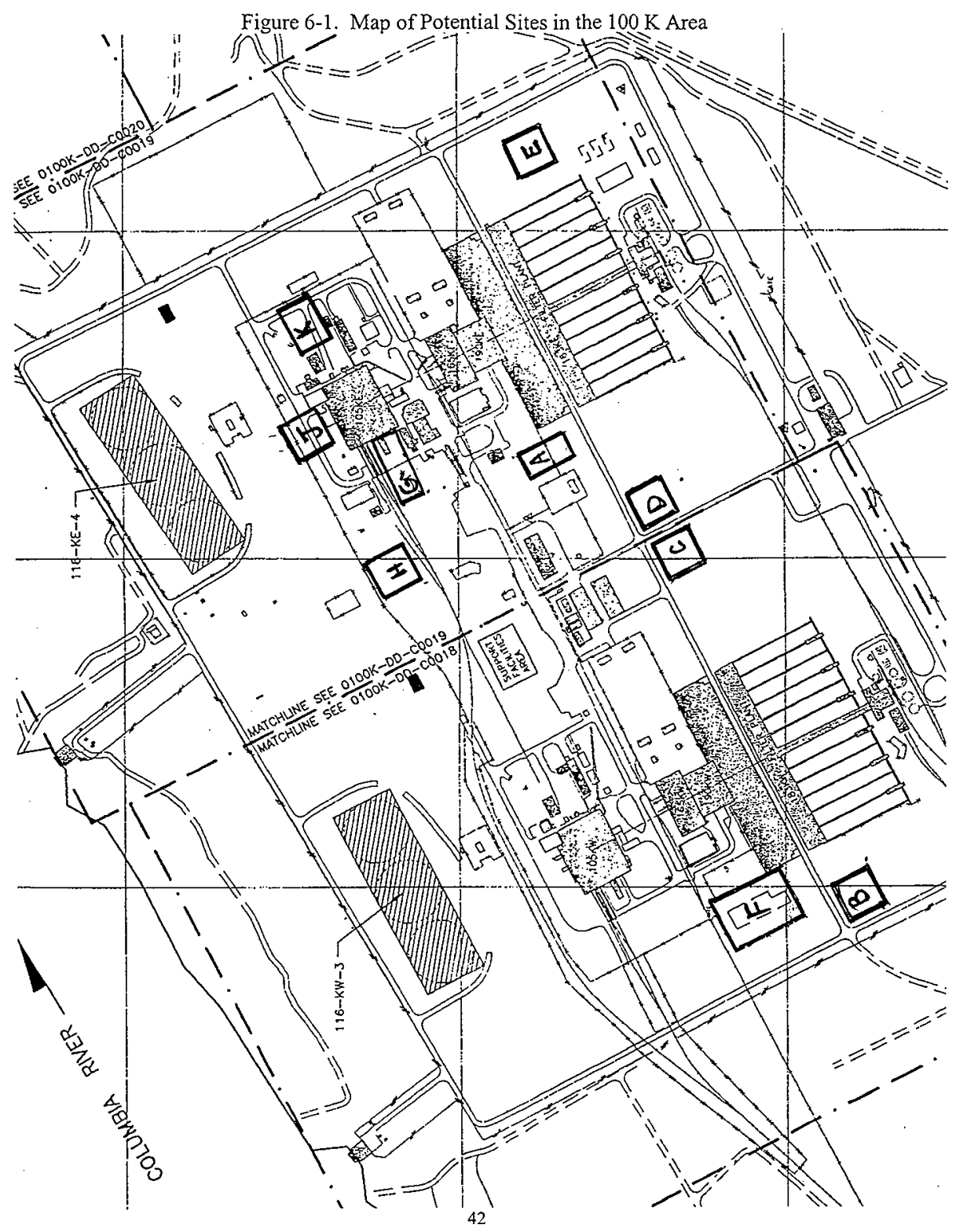




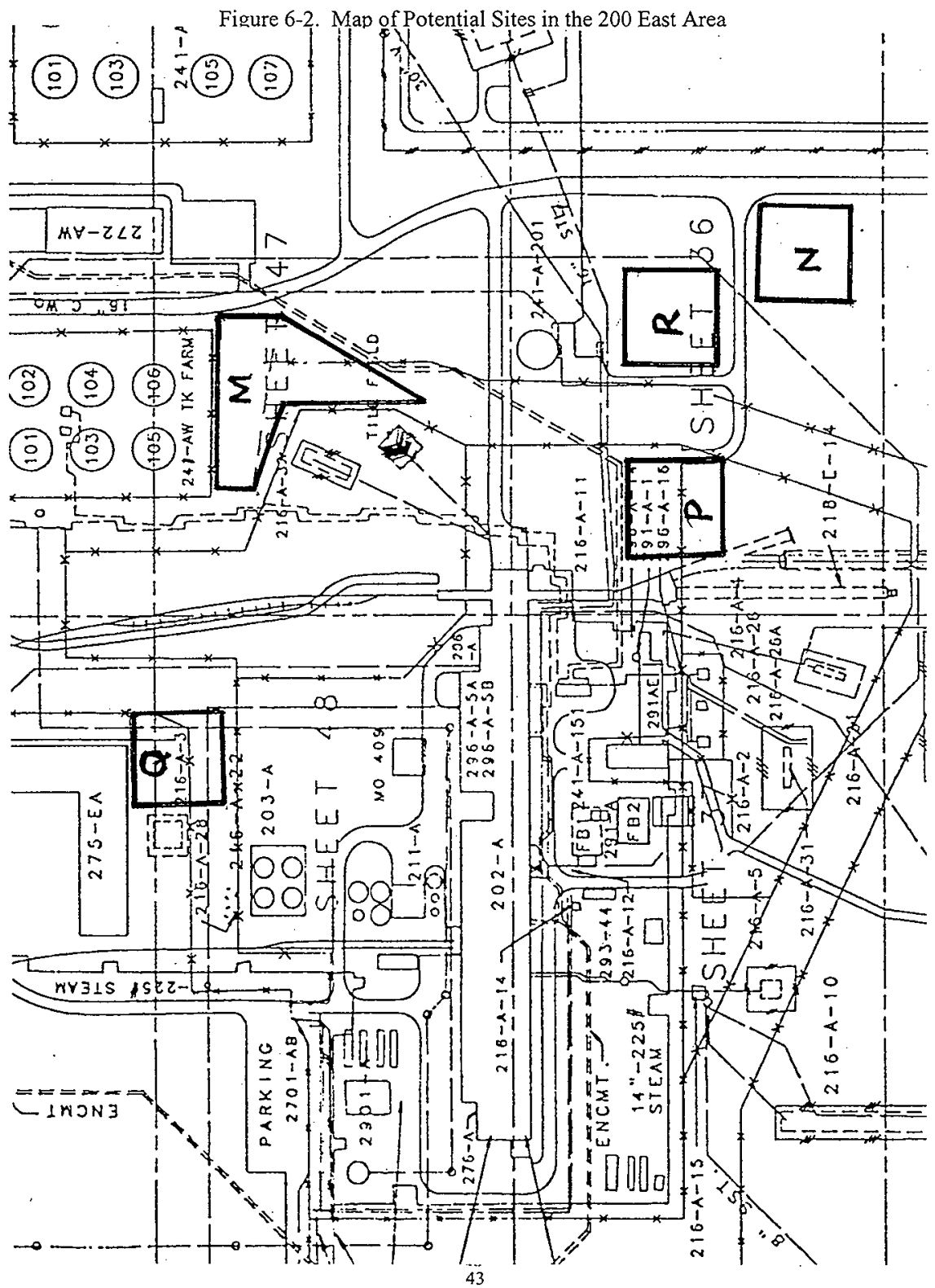




\subsection{EVALUATION OF POTENTIAL STAND-ALONE SITES}

The preliminary facility layout drawings for the alternative study indicate that an area approximately $30.4 \mathrm{~m} \mathrm{x} 33.5 \mathrm{~m}$ (100' $\left.\times 110^{\prime}\right)$ or $1020 \mathrm{~m}^{2}$ would be required for a stand alone sludge treatment facility. Attached to this would be a $15 \mathrm{~m} \times 18\left(50^{\prime}\right.$ x $60^{\prime}$ ) office and change room annex: Three bulk chemical tanks, water makeup tanks, a batch plant for grout, and some miscellaneous equipment would be located outside the building. In addition to the facility itself, space will be needed for bringing transport vehicles into and out of the facility. An additional area of approximately $1300 \mathrm{~m}^{2}$ is needed for auxiliary support equipment, and storage space, and utility setbacks.

The size of a stand-alone facility at $100 \mathrm{~K}$ could be reduced a little if the neutralization part of the process is done in a small facility located at the AW Tank Farm. This could be an addition to the 204-AR unloading station. The size of the hot cell could be reduced by $5-10 \%$ since it would not have to house the large neutralization tank. The storage and makeup tanks for $\mathrm{NaOH}$ and $\mathrm{NaNO}_{2}$, which would be located in a cold area, also would not be needed.

\subsubsection{Site A}

Site $\mathrm{A}$ is located between $\mathrm{K}$-East and $\mathrm{K}$-West Basins as can be seen from Figure 6-1. It is, however, in a position which would interfere with the main telecommunication conduit and manhole system. It is also in the path for major electrical corridors (Diebel 1996).

\subsubsection{Site B}

Site $B$ is located just south of the CVDF. The distance from the basins makes this site unattractive, however, piping would still be feasible.

\subsubsection{Site C}

Site $\mathrm{C}$ is located in the path of electrical corridors.

\subsubsection{Site $\mathrm{D}$}

Site $\mathrm{D}$ is also located in the path of electrical corridors.

\subsubsection{Site $\mathrm{E}$}

Site $\mathrm{E}$ is also located in the path of electrical corridors.

\subsubsection{Site $\mathrm{G}$}

Site $\mathrm{G}$ is adjacent to the west of $\mathrm{KE}$ basin. There are two wells that fall within the boundaries of the proposed site, and one well nearby. There is a waste crib that lies in close proximity to the site. There is also the I-beam superstructure and walkways that were used to maintain the Reactor Control Rod drives that will have to be removed in order to obtain the space required for the site. 


\subsubsection{Site $\mathrm{H}$}

Site $\mathrm{H}$ is located in the path of electrical corridors. There are also three wells that may cause interference around this site.

\subsubsection{Site J}

Site $\mathrm{J}$ is adjacent to the north of the $\mathrm{KE}$ basin. The proposed site lies on a road that would have to be moved. There are also many wells and sampling stations that interfere with this site.

\subsubsection{Site K}

Site $\mathrm{K}$ is located just east of the $\mathrm{KE}$ basin. Like Site $\mathrm{J}$, this site lies on roads that would have to be moved. This site lies in close proximity to a drain field and three wells. This proposed site would be cluttered among existing structures.

\subsubsection{Site M}

Site $\mathrm{M}$ is located just south of the AW tank farms. A waste crib and tile field on the west and a pipe encasement on the east bound the site on both sides. There is a secured area within the site that would be interrupted, however, there is no known impact on situating the site in this location. This looks to be the most attractive site in the 200 area; the location makes it feasible to pipe the treated and neutralized sludge into tank AW-105.

\subsubsection{Site N}

Site $\mathrm{N}$ is located approximately $300 \mathrm{~m}$ south of the $\mathrm{AW}$ tank farms. There is a road bordering the site on both the north and the east. There is a contaminated condensate line and a pipe encasement between this site and the AW Tank Farm.

\subsubsection{Site $P$}

Site $\mathbf{P}$ is located just southeast of the Plutonium/Uranium Extraction Facility (PUREX). An abandoned anode conductor lies on the site. A contaminated condensate line and a pipe encasement border the site on the north. A $2.4 \mathrm{kV}$ electrical corridor borders the site on the south. The PUREX waste storage tunnel is in close proximity to the site on the west.

\subsubsection{Site Q}

Site $Q$ is located just south of the 275 Warehouse. The site is in the direct path of electrical corridors. There is a waste crib bordering the site on the west and a retaining wall and railroad tracks on the east.

\subsubsection{Site $\mathrm{R}$}

Site $\mathrm{R}$ is located approximately $200 \mathrm{~m}$ south of the AW tank farms. There are roads bordering the site on both the west and the south. There is a contaminated condensate line and a pipe encasement between this site and the AW Tank Farm. 


\subsection{RECOMMENDATION FOR NEW STAND-ALONE FACILITY SITE}

\subsubsection{Development Criteria and Evaluation for Potential Sites in $100 \mathrm{~K}$}

The potential sites for a standalone facility in the $100 \mathrm{~K}$ area (described in sections 6.3 ) were compared using the criteria described in section 6.2. The comparison was done by preparing the matrix shown in Table 6-1.

Table 6-1. Selection Criteria for Sludge Treatment Stand-alone Facility in $100 \mathrm{~K}$ (Sheet 1)

\begin{tabular}{|c|c|c|c|c|c|}
\hline \multirow{2}{*}{\multicolumn{2}{|c|}{ Selection Criteria }} & \multicolumn{4}{|c|}{$100 \mathrm{~K}$-Sites Considered } \\
\hline & & Requirement & $\mathbf{A}$ & $\mathbf{B}$ & $\mathrm{C}$ \\
\hline \multicolumn{2}{|c|}{ Fulfillment of Space Requirement } & $2600 \mathrm{~m}^{2}$ & Yes & Yes & Yes \\
\hline \multicolumn{2}{|c|}{ Underground Obstructions } & None & Tunnel & None & None \\
\hline \multicolumn{2}{|c|}{ 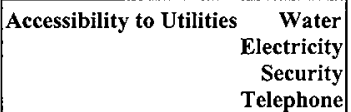 } & $\begin{array}{l}\text { (Yes) } 10 \\
\text { (Yes) } 10 \\
\text { (Yes) } 10 \\
\text { (Yes) } 10\end{array}$ & $\begin{array}{c}10 \\
5 \\
10 \\
10\end{array}$ & $\begin{array}{c}7 \\
10 \\
5 \\
3\end{array}$ & $\begin{array}{l}6 \\
7 \\
5 \\
5\end{array}$ \\
\hline \multicolumn{2}{|c|}{$\begin{array}{l}\text { Accountability of } \\
\text { Transfer/Transport Study }\end{array}$} & \begin{tabular}{|l} 
Opt 1 (MCO, short \\
pipe) \\
Opt 3 (MCO, large \\
cask) \\
Opt 11 (short \\
pipe/large cask)
\end{tabular} & Opt 11 & Opt 3 & Opt 3 \\
\hline \multirow{2}{*}{\multicolumn{2}{|c|}{$\begin{array}{l}\text { Facility Location (relative to the } \\
\text { Columbia River) } \\
\text { Interference with Other } \\
\text { Projects/Operations }\end{array}$}} & Farther is better & Near & Near & Near \\
\hline & & Impact is bad & None & None & None \\
\hline \multicolumn{2}{|c|}{ Disruption of Infrastructure } & Disnuption is bad & $\begin{array}{l}\text { Over tunnel } \\
\text { Close to } \\
\text { hydrant }\end{array}$ & $\begin{array}{l}\text { Good } \\
\text { vehicle/foot } \\
\text { traffic } \\
\text { Distance from } \\
\text { waste sites }\end{array}$ & \begin{tabular}{|l} 
Good \\
vehicle/foot \\
traffic \\
Distance \\
from waste \\
sites
\end{tabular} \\
\hline \begin{tabular}{|l|}
$\begin{array}{l}\text { Surrounding Ground } \\
\text { Contamination }\end{array}$ \\
\end{tabular} & $\begin{array}{c}\text { Surface } \\
\text { Subsurface }\end{array}$ & $\begin{array}{l}\text { Good (10) } \\
\text { Good (10) }\end{array}$ & $\begin{array}{c}10 \\
5\end{array}$ & $\begin{array}{l}10 \\
10\end{array}$ & $\begin{array}{c}\text { Unknown } \\
8\end{array}$ \\
\hline
\end{tabular}


Table 6-1. Selection Criteria for Sludge Treatment Stand-alone Facility in $100 \mathrm{~K}$ (Sheet 2)

\begin{tabular}{|c|c|c|c|c|c|}
\hline \multirow{2}{*}{\multicolumn{2}{|c|}{ Selection Criteria }} & \multicolumn{4}{|c|}{$100 \mathrm{~K}-$ Sites Considered } \\
\hline & & Requirement & $\mathbf{D}$ & $\mathbf{E}$ & G \\
\hline \multicolumn{2}{|c|}{ Fulfillment of Space Requirement } & $2600 \mathrm{~m}^{2}$ & Yes & Yes & Yes \\
\hline \multicolumn{2}{|c|}{ Underground Obstructions } & None & None & None & Footings \\
\hline \multicolumn{2}{|c|}{ 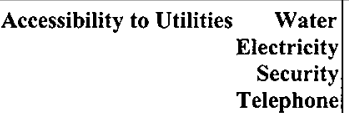 } & $\begin{array}{l}\text { (Yes) } 10 \\
\text { (Yes) } 10 \\
\text { (Yes) } 10 \\
\text { (Yes) } 10\end{array}$ & $\begin{array}{c}5 \\
\text { Yes } \\
5 \\
\text { Yes }\end{array}$ & $\begin{array}{c}4 \\
\text { Yes } \\
5 \\
\text { Yes }\end{array}$ & $\begin{array}{c}8 \\
\text { Yes } \\
10 \\
\text { Yes }\end{array}$ \\
\hline \multicolumn{2}{|c|}{\begin{tabular}{|l} 
Accountability of \\
Transfer/Transport Study
\end{tabular}} & $\begin{array}{l}\text { Opt } 1 \text { (MCO, short } \\
\text { pipe) } \\
\text { Opt } 3 \text { (MCO, large } \\
\text { cask) } \\
\text { Opt } 11 \text { (short } \\
\text { pipe/large cask) }\end{array}$ & Opt 3 & Opt 3 & Opt 11 \\
\hline \multicolumn{2}{|c|}{$\begin{array}{l}\text { Facility Location (relative to the } \\
\text { Columbia River) }\end{array}$} & Farther is better & Near & Near & Near \\
\hline \multicolumn{2}{|l|}{$\begin{array}{l}\text { Interference with Other } \\
\text { Projects/Operations } \\
\end{array}$} & Impact is bad & None & None & Fuel Removal \\
\hline \multicolumn{2}{|c|}{ Disruption of Infrastructure } & Disruption is bad & \begin{tabular}{|l} 
- \\
Good \\
vehicle/foot \\
traffic \\
Distance from \\
waste sites
\end{tabular} & 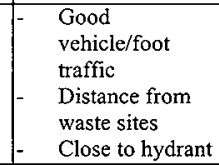 & $\begin{array}{l}\text { Remove } \\
\text { substructure } \\
\text { Close road }\end{array}$ \\
\hline $\begin{array}{l}\text { Surrounding Ground } \\
\text { Contamination }\end{array}$ & \begin{tabular}{|c|} 
Surface \\
Subsurface
\end{tabular} & $\begin{array}{l}\text { Good (10) } \\
\text { Good (10) }\end{array}$ & $\begin{array}{c}10 \\
8\end{array}$ & $\begin{array}{c}10 \\
8\end{array}$ & Unknown \\
\hline
\end{tabular}


Table 6-1. Selection Criteria for Sludge Treatment Stand-alone Facility in $100 \mathrm{~K}$ (Sheet 3)

\begin{tabular}{|c|c|c|c|c|}
\hline \multirow[b]{2}{*}{ Selection Criteria } & \multicolumn{4}{|c|}{$100 \mathrm{~K}-$ Sites Considered } \\
\hline & Requirement & $\mathbf{H}$ & $\mathbf{J}$ & $\mathbf{K}$ \\
\hline Fulfillment of Space Requirement & $2600 \mathrm{~m}^{2}$ & Yes & Yes & Yes, but tight \\
\hline Underground Obstructions & None & None & Wells & $\begin{array}{l}\text { Need Ground } \\
\text { Survey }\end{array}$ \\
\hline 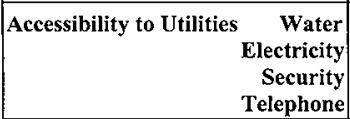 & $\begin{array}{l}\text { (Yes) } 10 \\
\text { (Yes) } 10 \\
\text { (Yes) } 10 \\
\text { (Yes) } 10\end{array}$ & $\begin{array}{c}2 \\
\text { Yes } \\
10 \\
\text { Yes }\end{array}$ & $\begin{array}{c}9 \\
\text { Yes } \\
8 \\
\text { Yes }\end{array}$ & $\begin{array}{c}3 \\
\text { Yes } \\
10 \\
\text { Yes }\end{array}$ \\
\hline \begin{tabular}{|l|} 
Accountability of \\
Transfer/Transport Study
\end{tabular} & $\begin{array}{ll} & \text { Opt } 1 \text { (MCO, short } \\
\text { pipe) } & \\
\text { Opt } 3(\mathrm{MCO}, \text { large } \\
\text { cask) } \\
\text { Opt } 11 \text { (short } \\
\text { pipe/large cask) }\end{array}$ & Opt 11 & Opt 11 & Opt 11 \\
\hline $\begin{array}{l}\text { Facility Location (relative to the } \\
\text { Columbia River) }\end{array}$ & Farther is better & Near & Near & Near \\
\hline $\begin{array}{l}\text { Interference with Other } \\
\text { Projects/Operations }\end{array}$ & Impact is bad & None & ITWS System & Blocked Road \\
\hline Disruption of Infrastructure & Disruption is bad & - Build new road & 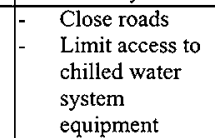 & $\begin{array}{ll}\text { - } & \text { Close roads } \\
\text { - } & \text { Close to } \\
\text { burial site }\end{array}$ \\
\hline \begin{tabular}{|l|l|}
$\begin{array}{l}\text { Surrounding Ground } \\
\text { Contamination }\end{array}$ & $\begin{array}{c}\text { Surface } \\
\text { Subsurface }\end{array}$ \\
\end{tabular} & $\begin{array}{l}\text { Good (10) } \\
\text { Good (10) }\end{array}$ & Unknown & Unknown & Unknown \\
\hline
\end{tabular}

There are no sites in the $100 \mathrm{~K}$ that are recommended for the sludge treatment facility location. The $100 \mathrm{~K}$ area is undesirable due to its proximity to the Columbia River. There are no sites in the $100 \mathrm{~K}$ area that are within the $\mathrm{MCO} /$ short pipe transport criteria.

Site $\mathrm{A}$ is unacceptable since it is located directly over an active tunnel. There are wells and sampling ports which lie on the area designated as Sites $\mathrm{J}$ and $\mathrm{H}$. Sites $\mathrm{G}, \mathrm{J}$, and $\mathrm{K}$ are located over existing roads which would have to be moved. Site $\mathrm{G}$ requires a removal of an existing substructure as well as underground obstructions. Site $G$ would also interfere with fuel removal, which is highly undesirable. Sites B, C, D, and E are too far away from the basins to fulfill the short pipe criteria and would result in an excess cost to transport via cask or long pipe. 


\subsubsection{Development Criteria and Evaluation for Potential Sites in 200 Area}

The potential sites for a standalone facility in the $200 \mathrm{E}$ area (described in sections 6.4) were compared using the criteria described in section 6.2 . The comparison was done by preparing the matrix shown in Table 6-2.

Table 6-2. Selection Criteria for Sludge Treatment Stand-alone Facility in 200 Area (Sheet 1)

\begin{tabular}{|c|c|c|c|}
\hline \multirow[b]{2}{*}{ Selection Criteria } & \multicolumn{3}{|c|}{200 Area - Sites Considered ${ }^{*}$} \\
\hline & Requirement & $\mathbf{M}$ & $\mathbf{N}$ \\
\hline Fulfillment of Space Requirement & $2600 \mathrm{~m}^{2}$ & Yes & Yes \\
\hline Underground Obstructions & None & None & None \\
\hline 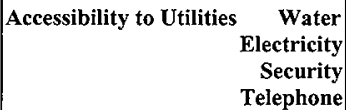 & $\begin{array}{l}\text { (Yes) } 10 \\
\text { (Yes) } 10 \\
\text { (Yes) } 10 \\
\text { (Yes) } 10\end{array}$ & Available & Available \\
\hline $\begin{array}{l}\text { Accountability of } \\
\text { Transfer/Transport Study }\end{array}$ & $\begin{array}{l}\text { Opt } 1 \text { (MCO, short } \\
\text { pipe) } \\
\text { Opt } 2 \text { (cask, short } \\
\text { pipe) } \\
\text { Opt } 3 \text { (MCO, large } \\
\text { cask) }\end{array}$ & Opt 1 & $\begin{array}{l}\text { Opt } 8(\mathrm{MCO} / \mathrm{long} \\
\text { pipe }) \text { or Opt } 3\end{array}$ \\
\hline $\begin{array}{l}\text { Facility Location (relative to the } \\
\text { Columbia) }\end{array}$ & Farther is better & Far & Far \\
\hline $\begin{array}{l}\text { Interference with Other } \\
\text { Projects/Operations }\end{array}$ & Impact is bad & None & None \\
\hline Disruption of Infrastructure & Disruption is bad & Security fences & \\
\hline $\begin{array}{l}\text { Surrounding Ground } \\
\text { Contamination } \\
\text { (subsurface) }\end{array}$ & $\begin{array}{l}\text { Good (10) } \\
\text { Good (10) }\end{array}$ & $\begin{array}{c}216-\mathrm{A}-32 \text { crib } \\
\text { (risk is } \\
\text { low/excavated } \\
\text { nearby at tanks) }\end{array}$ & $\begin{array}{l}10 \\
10\end{array}$ \\
\hline
\end{tabular}


Table 6-2. Selection Criteria for Sludge Treatment Standalone Facility in 200 Area (Sheet 2)

\begin{tabular}{|c|c|c|c|c|}
\hline \multirow[b]{2}{*}{ Selection Criteria } & \multicolumn{4}{|c|}{200 Area - Sites Considered } \\
\hline & Requirement & $\mathbf{P}$ & $\mathbf{Q}$ & $\mathbf{R}$ \\
\hline Fulfillment of Space Requirement & $2600 \mathrm{~m}^{2}$ & Yes & Yes & Yes \\
\hline Underground Obstructions & None & None & $216-\mathrm{A}-3 \mathrm{crib}$ & None \\
\hline 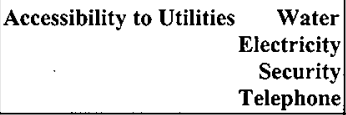 & $\begin{array}{l}\text { (Yes) } 10 \\
\text { (Yes) } 10 \\
\text { (Yes) } 10 \\
\text { (Yes) } 10\end{array}$ & Available & Available & Available \\
\hline $\begin{array}{l}\text { Accountability of } \\
\text { Transfer/Transport Study }\end{array}$ & $\begin{array}{l}\text { Opt } 1 \text { (MCO, short } \\
\text { pipe) } \\
\text { Opt } 2 \text { (cask, short } \\
\text { pipe) } \\
\text { Opt } 3 \text { (MCO, large } \\
\text { cask) }\end{array}$ & Opt 1 & Opt 1 & Opt 1 \\
\hline $\begin{array}{l}\text { Facility Location (relative to the } \\
\text { Columbia) }\end{array}$ & Farther is better & Far & Far & Far \\
\hline \begin{tabular}{|l|} 
Interference with Other \\
Projects/Operations
\end{tabular} & Impact is bad & None & $\begin{array}{c}\text { Crossing PUREX } \\
\text { railroad cut }\end{array}$ & None \\
\hline Disruption of Infrastructure & Disruption is bad & $\begin{array}{l}\text { Fencing } \\
\text { Condensate } \\
\text { lines } \\
\text { Pipe } \\
\text { encasement } \\
\end{array}$ & $\begin{array}{l}\text { Need to keep } \\
\text { railroad open }\end{array}$ & \begin{tabular}{|l} 
Condensate \\
lines \\
Pipe \\
encasement
\end{tabular} \\
\hline \begin{tabular}{|l|}
$\begin{array}{l}\text { Surrounding Ground } \\
\text { Contamination } \\
\text { (subsurface) }\end{array}$ \\
\end{tabular} & $\begin{array}{l}\text { Good (10) } \\
\text { Good (10) }\end{array}$ & $\begin{array}{l}10 \\
10\end{array}$ & $216-\mathrm{A}-3 \mathrm{crib}$ & $\begin{array}{l}10 \\
10\end{array}$ \\
\hline
\end{tabular}

Site $\mathrm{M}$ is the most desirable site in both the 200 area and $100 \mathrm{~K}$ area. There is more than enough empty land to fulfill the space requirement. It is a prime candidate for fulfilling the short pipe criteria. It is located far away from the Columbia River. There are no underground obstructions as well as no interference with other ongoing projects. The 216-A-32 waste crib is adjacent to the site. This crib exhibits a very low risk with a receipt of approximately 4,000-L of PUREX crane maintenance, facility floor, sink, and shower drainage. The crib contains a recorded activity of less than 1-curie total beta (EDV). The site has been excavated at the tank farms, which is also a factor in determining low risk.

Site $\mathrm{P}$ is not recommended for the sludge treatment facility location due to the contaminated condensate line and pipe encasement that run near or on the site. Sites $P, R$ and $\mathrm{N}$ are not recommended for the contaminated condensate lines and pipe encasement that would have to be crossed when installing the waste line to the AW tank. Site $\mathrm{Q}$ is not recommended since it lies adjacent to crib 216-A-3, which has a recorded disposal volume of $3,050,000$ liters of process effluent (EDV). This amount of liquid deposited into crib 216-A-3 would result in a sizeable plume which would create a potential 
problem during site excavation. Site $Q$ would also require crossing a WIDS site in the installation of the waste line to the AW-105 tank.

\section{ENGINEERING ANALYSIS AND RECOMMENDATION}

The engineering analysis of all the available facilities and siting alternatives narrow siting options in sections 5.5 and 6.6 above. In section 5.5, T Plant was found to be the only existing facility considered that had enough cell space for a sludge treatment facility. The other facilities did not have enough hot cell space and did not have a suitable location to build new hot cells. In section 6.6, site $\mathrm{M}$ which is located adjacent to the south side of the AW Tank Farm, was found to be the best location for a stand-alone facility.

The consideration of being close to DST AW-105 for transfer and transportation purposes, being away from the river and site boundaries for siting of a chemical treatment facility provide the siting in the 200 Areas as the best choice. Since this facility will have a very short primary mission of less than three years it is desirable to construct a facility at a minimum cost. Siting the facility away from public access (the river and site boundary) will allow for lower costs associated with the Design Basis Accident mitigation and will better support the site mission of cleaning up the sites close to the river.

The Site M located just south of the AW Tank Farm is the best site and is recommended as the principle site for the conceptual design of the Sludge Treatment Facility. Section 6.6 provides the basis for selecting this site over the other 200 Area sites. It is recommended that the alternate Site $R$ which is located 200 meters south of AW Tank Farm also be used as the alternate site through the conceptual design process. Costs, schedule, and risks should also be provided for this site as part of the conceptual design.

The $T$ Plant canyon deck is being considered for the site of a facility to process the remote handled TRU waste currently stored in the $200 \mathrm{~W}$ area (TPA milestone M91). If the T Plant structure and documentation are upgraded to process remote handled TRU, then most of the upgrades that would be needed to treat the $\mathrm{K}$ Basin sludge probably will already be done. The treatment equipment and control system would need to be installed, but the building structure and shielding would already be in place. After the sludge treatment campaign is completed, the sludge treatment equipment probably could be used to process some of the remote handled TRU waste.

If the burden of T Plant upgrades to process sludge fell entirely to the Spent Nuclear Fuel Project, the cost might equal or exceed the cost of a new standalone facility. The extent of the needed upgrades are as yet unknown, but this assessment is made based upon needed improvement to other similar facilities for similar missions. If $T$ Plant is considered for an RH TRU mission, and $\mathrm{K}$ Basin sludge could be processed with it as part of a shared mission and managed as RH TRU waste rather than go to TWRS, the option to use T Plant should be revisited. 
The difference between considering T Plant for sludge treatment and the evaluations of other canyon facilities for future missions is that the canyon deck and pool cell are being considered in T Plant while only the canyon cells were considered for future missions in most of the other studies. Upgrading cells to ensure secondary containment for hazardous waste is more difficult than installing new equipment with secondary containment on the canyon deck. 


\section{REFERENCES}

Chang, H. L., 1997, K Basin Sludge Removal Sludge Pretreatment System, HNF-SDSNF-PCR-002, Rev 0, Fluor Daniel Northwest, Richland, WA.

Covey, L. I., 1998, Waste Encapsulation and Storage Facility Safety Equipment List, HNF-SD-WM-SEL-008, Rev 5, B\&W Hanford Co, Richland, WA.

Covey, L. I., 1998, Waste Encapsulation and Storage Facility Basis for Interim Operation, HNF-SD-WM-BIO-002, Rev 0, B\&W Hanford Co, Richland, WA.

Diebel, J. A., 1996, Cold Vacuum Drying Facility Site Evaluation Report, WHC-SDSNF-SE-001, Rev 0, ICF Kaiser Hanford, 1996.

DOE/MA/06212-2, SITE DEVELOPMENT PLANNING HANDBOOK SUPPLEMENT, An Illustrative case Study Problem in Facilities Planning.

DOE, 1996a, Good Practice Guide GPG-FM-033 Comprehensive Land-Use Planning Process Guide, March 1996.

DOE, 1996b, Good Practice Guide GPG-FM-024 Site-Selection Process, March 1996.

DOE-RL, 1999, Focused Feasibility Study for the K Basins Interim Remedial Action, DOE/RL-98-66, Rev. 0, U.S. Department of Energy, Richland Operations Office, Richland, WA.

Environmental Data Viewer (EDV): http://wilbur/mojomap/viewlibrary.htm.

Fowler, K. D., 1995, Internal memo to C. J. Alderman, "K Basin Sludge to TWRS:

Transfer Feasibility", Westinghouse Hanford Co. letter 71310-95-005, January 25, 1995.

Hillesland, K., Moore, F. W., 1999, ALARA Sludge Treatment Dose Estimate Spreadsheet Deliverable, SNF-4471, Rev. O, Flour Daniel Northwest, Inc and Numatec Hanford Corporation, Richland, WA.

Klem, M. J., F. W. Moore, 1999, Engineering Evaluation of Transfer and Transport Concepts Applicable to Sludge Treatment Project, HNF-3757, Numatec Hanford Corporation, Richland, WA.

LATA/BNFL, 1969, Removal Plan for Shippingport Pressurized Water Reactor Core 2 Blanket Fuel Assemblies from T Plant to the Canister Storage Building, WHC-SD-WMES-394, Rev 0, Los Alamos Technical Associates Inc. and BNFL Inc., Richland, WA. 
Meyer, M. F., 1998, Interim Safety Analysis for Solid Waste Facilities (T Plant), HNFSD-WM-ISB-006, Rev 1, Waste Management Federal Services of Hanford, Inc, Richland, WA.

Pearce, K. L., G. A. Whyatt, A. J. Schmidt, J. D. Hover, 1999, C. A. Petersen, 1999, Sludge Treatment Alternatives Analysis, HNF-4097, Rev 0, Numatec Hanford Corporation, Richland, WA.

Pili-Vincens, C., 1998, Safety Analysis Report for the CVD Facility Phase II Supporting Installation of Process Systems, HNF-SD-SNF- SAR-002, Rev. 4, Numatec Hanford Corporation, Richland, WA.

Ryan, J, 1993, "Neutralization of Uranyl Nitrate Solutions", letter dated, January, 21, 1993 Pacific Northwest Laboratory

Wallace, D. A., 1995, Letter to S. A. Brisban, "204-AR Piping for Sludge Transfer", ICF Kaiser Hanford letter SCS-W-95-1492, May 23, 1995.

Weaver, L. L., 1998, 222-S Laboratory Interim Safety Basis, HNF-SD-CP-ISB-002, Rev. 3, Numatec Hanford Corporation, Richland, WA.

Westra, A. G., T. A. Flament, L. de Lamartinie, 1998a, K Basin Sludge Treatment Process Description, HNF-2735, Rev. 0, Numatec Hanford Corporation, Richland, WA.

Westra, A. G., 1998b, Maintenance and Operations Study for K Basin Sludge Treatment, HNF-3591, Rev. 0, Numatec Hanford Corporation, Richland, WA.

Williams, N. H., 1999, Letter to J. M. Augustenborg, "Contract Number DE-AC0696RL13200 - Spent Nuclear Fuel Sludge Treatment Path Forward Recommendation, Fluor Daniel Hanford letter FDH-9953935, June 10, 1999.

Womack, J. C., 1996, Spent Nuclear Fuel Project Systems Engineering Management Plan, WHC-SD-SNF-SEMP-001, Rev. 0, Westinghouse Hanford Company, Richland, WA.

Ziada, H. H., 1999, Letter "Analysis of CVDF Floor for Support of Hot Cell”, June 1999. 


\section{DISTRIBUTION SHEET}

\begin{tabular}{|c|c|c|c|c|c|}
\hline To & From & & & Page 1 of 1 & \\
\hline Distribution & $\begin{array}{l}\text { Numatec Hanfo } \\
\text { SNE Sludge De }\end{array}$ & $\begin{array}{l}\text { d Corport } \\
\text { inition } \mathrm{P}\end{array}$ & $\begin{array}{l}\text { on } \\
\text { oject }\end{array}$ & Date June 14 & 1999 \\
\hline Project Title/Work Order & & & & EDT No. 6263 & \\
\hline SNF Sluage Definition Project, & $\mathrm{HNF}-4286$ & & & ECN No. NA & \\
\hline Name & MSIN & $\begin{array}{c}\text { Text } \\
\text { With All } \\
\text { Attach. }\end{array}$ & Text Only & $\begin{array}{l}\text { Attach./ } \\
\text { Appendix } \\
\text { Only }\end{array}$ & $\begin{array}{c}\text { EDT/ECN } \\
\text { Only }\end{array}$ \\
\hline D. E. Bullock & R3-86 & $\mathbf{x}$ & & & \\
\hline T. A. Flament & но-34 & $x$ & & & \\
\hline E. W. Gerber & R3-11 & $x$ & & & \\
\hline M. J. Klem & R3-86 & x & & & \\
\hline s. C. Klimper & HO-34 & $\mathbf{x}$ & & & \\
\hline F. W. Moore & но-34 & $\mathbf{x}$ & & & \\
\hline L. B. MoDaniel & R3-11 & $\boldsymbol{x}$ & & & \\
\hline D. E. MCKenney & H6-30 & $\mathbf{x}$ & & & \\
\hline K. L. Pearce & но-34 & $\mathbf{x}$ & & & \\
\hline D. R. Precechtel & $\times 3-85$ & $\mathbf{x}$ & & & \\
\hline พ. พ. Rutherford & но-34 & $\mathbf{x}$ & & & \\
\hline J. H. Siemer & но-34 & $\mathbf{x}$ & & & ? \\
\hline A. G. Westra & R3-86 & $\mathbf{x}$ & & & \\
\hline R. T. Wilde & H6-10 & $\mathbf{x}$ & & & \\
\hline H. A. Wyman & R3-86 & $\mathbf{x}$ & & & \\
\hline SNF Project Files A-13B & H6-08 & $\mathbf{x}$ & & & \\
\hline Central Files & B1-07 & $\mathbf{x}$ & & & \\
\hline DOE-RL Reading Room & $\mathrm{H} 2-53$ & $\mathbf{x}$ & & & \\
\hline
\end{tabular}

